\title{
Marilene Chaves Silvestre
}

\section{Avaliação da dermatite de contato alérgica ao níquel através da técnica de imuno-histoquímica}

Tese apresentada à Faculdade de Medicina da Universidade de São Paulo para obtenção do título de Doutor em Ciências

Programa de Dermatologia

Orientador: Prof. Dr. Vitor Manoel Silva dos Reis

São Paulo

2017 
Dados Internacionais de Catalogação na Publicação (CIP)

Preparada pela Biblioteca da

Faculdade de Medicina da Universidade de São Paulo

Creprodução autorizada pelo autor

\section{Silvestre, Marilene Chaves}

Avaliação da dermatite de contato alérgica ao níquel através da técnica de imunohistoquímica / Marilene Chaves Silvestre. -- São Paulo, 2017.

Tese(doutorado)--Faculdade de Medicina da Universidade de São Paulo. Programa de Dermatologia.

Orientador: Vitor Manoel Silva dos Reis.

Descritores: 1.Dermatite de contato 2.Dermatite alérgica de contato 3.Alergia e imunologia 4.Níquel 5.Imuno-histoquímica 6.Citocinas

USP/FM/DBD-134/17 


\section{AGRADECIMENTOS}

Aos meus pais, João e Terezinha, pelas orações e apoio incondicional, nos momentos de alegrias e dificuldades.

Ao Prof. Dr. Vitor Manoel Silva dos Reis, pelas orientações e apoio ao longo de toda caminhada para a realização desta pós-graduação no programa de dermatologia, contribuindo para meu crescimento científico e intelectual.

Ao médico patologista Prof. Dr. Sebastião Alves Pinto e à bióloga Profa. Dra. Carla Pagliari, pelo apoio e pela realização das técnicas de imuno-histoquímicas.

Ao Wellington Luiz Ferreira da Silva, pela realização da quantificação das reações de imuno-histoquímica.

Ao Prof. Dr. Mario Piscoya, pela análise estatística e orientações. 


\section{NORMALIZAÇÃO ADOTADA}

Esta tese está de acordo com as seguintes normas, em vigor no momento desta publicação:

Referências: adaptado de International Committee of Medical Journals Editors (Vancouver).

Universidade de São Paulo. Faculdade de Medicina. Divisão de Biblioteca e Documentação. Guia de apresentação de dissertações, teses e monografias. Elaborado por Anneliese Carneiro da Cunha, Maria Julia de A. L. Freddi, Maria F. Crestana, Marinalva de Souza Aragão, Suely Campos Cardoso, Valéria Vilhena. 3a ed. São Paulo: Divisão de Biblioteca e Documentação; 2011.

Abreviaturas dos títulos dos periódicos de acordo com List of Journals Indexed in Index Medicus. 


\section{SUMÁRIO}

Lista de abreviaturas

Lista de figuras

Lista de tabelas

Lista de gráficos

Resumo

Abstract

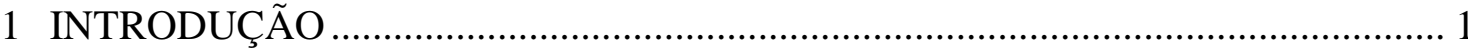

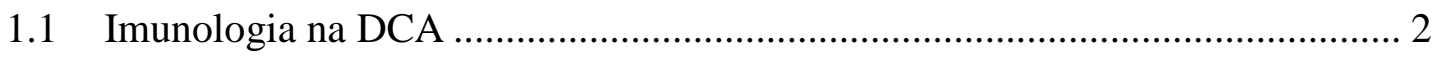

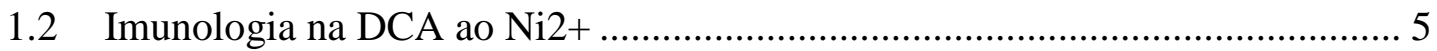

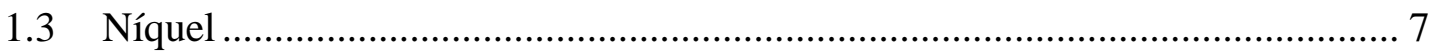

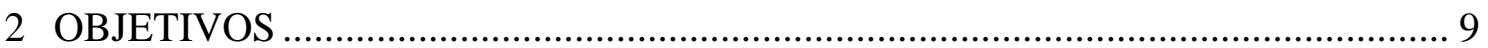

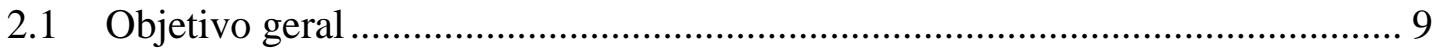

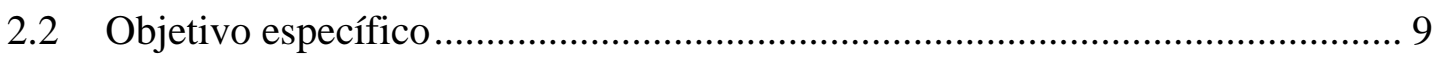

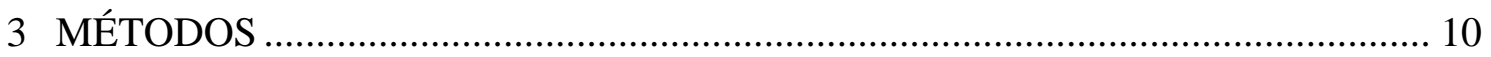

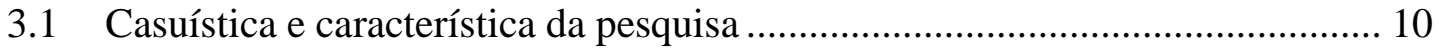

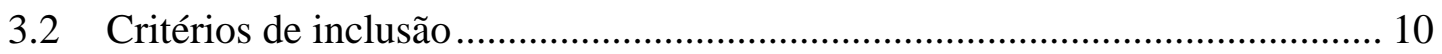

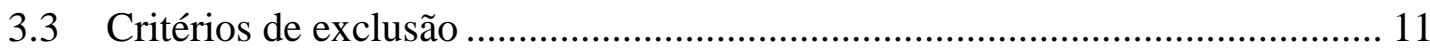

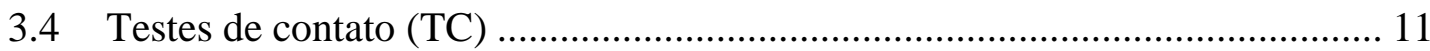

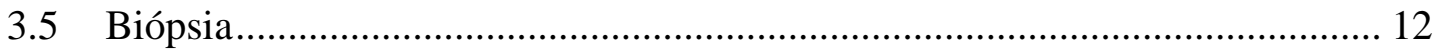

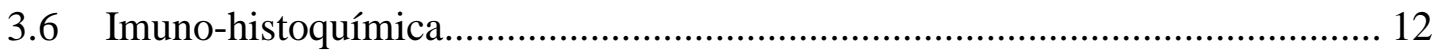

3.6.1 Coleta e preparação do material .......................................................... 12

3.6.2 Procedimentos de pré-tratamento ..................................................... 13

3.6.3 Padronização dos títulos ................................................................ 13

3.6.4 Procedimento de coloração.................................................................. 13

3.7 Quantificação das reações de imuno-histoquimica ........................................ 15

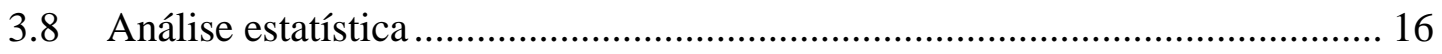

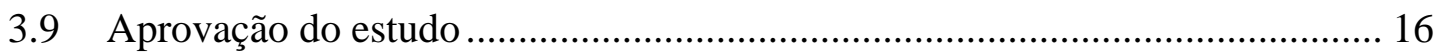

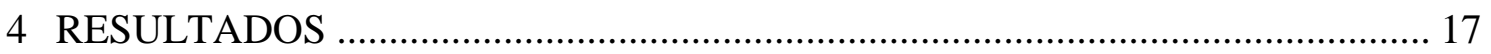

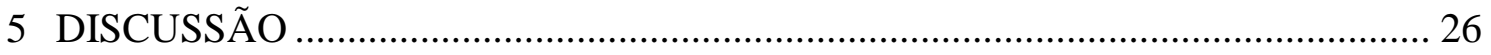

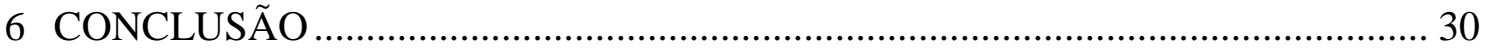

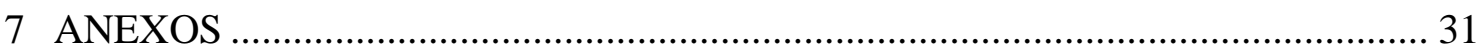

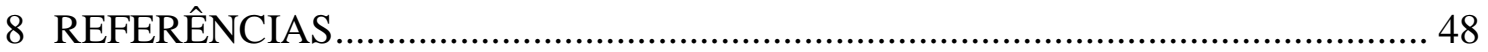




\section{LISTA DE ABREVIATURAS}

\begin{tabular}{|c|c|}
\hline APCs & Antigen-Presenting Cells \\
\hline CTLs & Cytotoxic T Lymphocytes \\
\hline $\mathrm{CV}$ & Coeficiente de variação \\
\hline DCA & Dermatite de contato alérgica \\
\hline DCs & Dendritic Cells \\
\hline $\mathrm{dDCs}$ & Dermal Dendritic Cells \\
\hline dLNs & Draining Lymph Nodes \\
\hline IFN- $\gamma$ & Interferon gama \\
\hline IL & Interleucina \\
\hline MHC & Major Histocompatibility Complex \\
\hline $\mathrm{Ni} 2+$ & Íon níquel \\
\hline NiSO4 & Sulfato de níquel \\
\hline NK & Natural Killer \\
\hline $\mathrm{Tc}$ & Linfócitos $\mathrm{T}$ citotóxicos \\
\hline TC & Testes de contato \\
\hline TCR & T-Cell Receptors \\
\hline Th & Linfócito T helper \\
\hline TLR-4 & Toll-Like Receptor 4 \\
\hline TNF- $\alpha$ & Fator de necrose tumoral alfa \\
\hline $\operatorname{Tr} 1$ & Linfócitos T reguladores 1 \\
\hline Tregs & Linfócitos T reguladores \\
\hline
\end{tabular}




\section{LISTA DE FIGURAS}

Figura 1 - Imuno-histoquímica. As amostras coradas revelaram resultados positivos para as citocinas: A: TNF- $\alpha$, B: INF- $\gamma$, C: IL-2, D: IL-4, E: IL-10, F: IL-13, G: IL-17 e H: IL-23. Aumento de 400x 


\section{LISTA DE TABELAS}

Tabela 1 - Análise quantitativa das reações de imuno-histoquímica de oito citocinas (IFN- $\gamma$, IL-2, IL-4, IL-10, IL-13, IL-17, IL-23 e TNF- $\alpha$ ), em 320 amostras (160 do eczema crônico e 160 do eczema agudo, ocasionados pelo níquel).

Tabela 2 - Estatísticas descritivas de oito citocinas (IFN- $\gamma$, IL-2, IL-4, IL-10, IL13, IL-17, IL-23 e TNF- $\alpha$ ), avaliadas pela técnica de imunohistoquímica, nos eczemas crônico e agudo ocasionados pelo níquel, em 20 pacientes

Tabela 3 - Avaliação da suposição de distribuição de probabilidade normal para os valores de oito citocinas (IFN- $\gamma$, IL-2, IL-4, IL-10, IL-13, IL-17, IL-23 e TNF- $\alpha$ ) nos eczemas crônico e agudo ocasionados pelo níquel, para $p$-value $<0,05$ não houve distribuição normal dos valores

Tabela 4 - Comparação das medianas de oito citocinas (IFN- $\gamma$, IL-2, IL-4, IL-10, IL-13, IL-17, IL-23 e TNF- $\alpha$ ) nos eczemas crônico e agudo ocasionados pelo níquel, para $p$-value $<0,05$ houve diferença entre as medianas

Tabela 5 - Bateria de testes de contato. Grupo brasileiro de estudos em dermatite de contato (GBEDC) 


\section{LISTA DE GRÁFICOS}

Gráfico 1 - Gráfico de caixas para as citocinas TNF- $\alpha$ e IFN- $\gamma$, segundo o tipo de eczema

Gráfico 2 - Gráfico de caixas para as citocinas IL-2 e IL-4, segundo o tipo de eczema

Gráfico 3 - Gráfico de caixas para as citocinas IL-10 e IL-13, segundo o tipo de eczema .23

Gráfico 4 - Gráfico de caixas para as citocinas IL-17 e IL-23, segundo o tipo de eczema 


\section{RESUMO}

Silvestre MC. Avaliação da dermatite de contato alérgica ao níquel através da técnica de imuno-histoquímica [tese]. São Paulo: Faculdade de Medicina, Universidade de São Paulo; 2017.

A dermatite de contato alérgica (DCA) ao íon níquel (Ni2+) é uma dermatose inflamatória frequente nos países industrializados. Envolve a ativação de células $\mathrm{T}$ específicas ao Ni2+, seguida da proliferação e indução de um perfil misto de citocinas, tanto pró-inflamatórias quanto reguladoras, sugerindo que vários subtipos de células $\mathrm{T}$ (helper - Th e citotóxica - Tc) estão envolvidos na resposta imune. Este estudo teve como objetivo a análise das citocinas TNF- $\alpha$, INF- $\gamma$, IL-2, IL-4, IL-10, IL-13, IL-17 e IL-23 pela técnica de imuno-histoquímica, para tentar identificar a prevalência de um ou mais subtipos de células $\mathrm{T}(\mathrm{Th} / \mathrm{Tc})$, nos eczemas crônico e agudo de pacientes com DCA ao Ni2+. Avaliamos 20 pacientes (17 mulheres e 3 homens, com idade mediana de 46 anos) apresentando eczema crônico, pelo contato cotidiano do paciente com o Ni2+. Foram coletadas duas biópsias de pele em cada um dos 20 pacientes, a primeira no local do eczema crônico ao Ni2+, antes da aplicação do teste de contato (TC); e a segunda no local do eczema agudo, provocado pelo TC com o sulfato de níquel, 48 horas após sua fixação, nas leituras positivo forte $(++)$ ou positivo muito forte $(+++)$. Foram 160 amostras de eczema agudo e 160 de eczema crônico, perfazendo um total de 320 amostras. Apenas três amostras foram excluídas devido a algum tipo de falha técnica, como, por exemplo, o descolamento dos cortes de pele da lâmina. Para a análise dos dados utilizou-se o software estatístico STATA versão 13. As amostras coradas revelaram resultados positivos para as oito citocinas estudadas, e estas apresentaram valores heterogêneos. Esta heterogeneidade foi medida pelo coeficiente de variação, indicando a variabilidade do conjunto dos dados obtidos. O TNF- $\alpha$, IFN- $\gamma$, IL-4, IL-13 e IL-17 tiveram prevalência maior no eczema crônico do que no eczema agudo, a IL-2 e IL-23 apresentaram maior prevalência no eczema agudo, em comparação com o eczema crônico e a IL-10 apresentou prevalência similar tanto no eczema agudo quanto no crônico, porém, estas prevalências foram muito baixas, em ambos os eczemas. O TNF- $\alpha$ foi a citocina que mais prevaleceu no eczema crônico e a IL-2 foi a mais prevalente no eczema agudo. Porém, estas prevalências foram estatisticamente significantes apenas para a IL-4 e IL-13. Verificamos, nos eczemas crônico e agudo, a presença de um perfil misto de citocinas dos subtipos de células $\mathrm{T}(\mathrm{Th} / \mathrm{Tc})$, sugerindo que as respostas imunes são expressas ao mesmo tempo. Entretanto, são necessários mais estudos para uma compreensão mais ampla sobre o perfil das citocinas na DCA ao Ni2+, o que poderia levar a novas abordagens terapêuticas.

Descritores: dermatite de contato; dermatite alérgica de contato; alergia e imunologia; níquel; imuno-histoquímica; citocinas. 


\begin{abstract}
Silvestre MC. Evaluation of nickel allergic contact dermatitis using the immunohistochemical technique [thesis]. São Paulo: "Faculdade de Medicina, Universidade de São Paulo"; 2017.

Allergic contact dermatitis (ACD) to nickel $(\mathrm{Ni}+2)$ is a inflammatory dermatosis, common in industrialized countries. It involves the activation of nickel-specific $\mathrm{T}$ cells, followed by the proliferation and induction of a mixed profile of both proinflammatory and regulatory cytokines, suggesting that several $\mathrm{T}$ cell subtypes (helper - Th and cytotoxic - Tc) are involved in the immune response. This study aimed to analyze the cytokines TNF- $\alpha$, INF- $\gamma$, IL-2, IL-4, IL-10, IL-13, IL-17 and IL-23 using the immunohistochemistry technique in order to try to identify the prevalence of one or more $\mathrm{T}$ cell subtypes $(\mathrm{Th} / \mathrm{Tc})$ in the chronic and acute eczema of patients with ACD to $\mathrm{Ni}+2$. We evaluated 20 patients (17 women and 3 men, median age of 46 years) with chronic eczema, by the patient's daily contact with $\mathrm{Ni}+2$. Two skin biopsies were collected in each of the 20 patients, the first at the site of the chronic eczema to $\mathrm{Ni}+2$, prior to the application of the contact test (CT); and the second at the site of acute eczema caused by CT with nickel sulphate, 48 hours after its fixation in the strong positive (++) or very strong positive (+++) readings. There were 160 samples of acute eczema and 160 of chronic eczema, a total of 320 samples. Only three samples were excluded due to some kind of technical failure, such as detachment of the skin cuts from the microscope slide. Statistical software STATA version 13 was used to analyze the data. The stained samples showed positive results for the eight cytokines studied, and these presented heterogeneous values. This heterogeneity was measured by the coefficient of variation, indicating the variability of the data set obtained. TNF- $\alpha$, IFN- $\gamma$, IL-4, IL-13 and IL-17 had a higher prevalence in chronic eczema than in acute eczema, IL-2 and IL-23 were more prevalent in acute eczema compared to chronic eczema and IL-10 presented similar prevalence in both acute and chronic eczema, however, a very low prevalence in both eczema. TNF- $\alpha$ was the most prevalent cytokine in chronic eczema and IL-2 was the most prevalent in acute eczema. However, these prevalences were statistically significant only for IL-4 and IL-13. In chronic and acute eczema, we observed the presence of a mixed cytokine profile of the $\mathrm{T}$ cell subtypes ( $\mathrm{Th} / \mathrm{Tc}$ ), suggesting that immune responses are expressed at the same time. However, further studies are needed for a broader understanding of the cytokine profile in ACD to $\mathrm{Ni}+2$, which could lead to new therapeutic approaches.
\end{abstract}

Descriptors: dermatitis, allergic contact; dermatitis, contact; allergy and immunology; nickel; immunohistochemistry; cytokines. 


\section{INTRODUÇÃO}

A dermatite de contato alérgica (DCA) é uma dermatose inflamatória frequente nos países industrializados, com grande impacto socioeconômico, ${ }^{1}$ sendo uma das doenças ocupacionais mais comuns. ${ }^{2}$ Especificamente, a DCA ao íon níquel (Ni2+) afeta uma grande fração da população em geral. ${ }^{3,4}$

Os tecidos epiteliais alinham as superfícies externa e interna do corpo e proporcionam um ambiente eficaz para proteger o organismo do mundo exterior. Estes tecidos não só fornecem funções de barreira, mas também contêm populações residentes de células que contribuem para a homeostase, vigilância, proteção e reparação do epitélio. ${ }^{5}$ Por ser a barreira mais externa do corpo humano, a pele é a primeira a entrar em contato com fatores químicos e físicos provenientes do meio ambiente, resultando na geração de antígenos não próprios. ${ }^{1,6}$ Assim, a pele tem a capacidade de desencadear respostas imunes. ${ }^{7}$

A DCA é causada devido ao contato da pele com os haptenos, se a exposição a este exceder o limiar individual de tolerância. ${ }^{8}$ A reação é, na realidade, uma resposta não controlada do sistema imune aos haptenos, e a perda dos mecanismos de tolerância leva à DCA. ${ }^{6,9}$ A barreira cutânea também é relevante no processo de sensibilização. Como os haptenos necessitam cruzar o estrato córneo, a integridade da pele é importante na manutenção da homeostasia. A presença de solução de continuidade e do processo inflamatório local pode favorecer a penetração dos alérgenos predispondo à alergia de contato. ${ }^{6,9,10}$

A prevalência da DCA depende do potencial sensibilizante do hapteno e da frequência e tempo de exposição a este. ${ }^{10,11}$ As condições de exposição também são importantes, pois podem favorecer o desenvolvimento da sensibilização, assim, a oclusão, a umidade e o contato do alérgeno com a pele lesada favorecem a sua penetração e a sensibilização. ${ }^{2}, 6,11 \mathrm{O}$ desenvolvimento da alergia de contato é o resultado da interação entre as exposições ambientais e a susceptibilidade individual. 
Assim, apenas uma fração dos indivíduos expostos se torna sensibilizada, desenvolvendo os sinais clínicos de inflamação da DCA. ${ }^{10,12}$ Estes se manifestam como um processo eruptivo cutâneo, que pode ser de várias modalidades clínicas: lesões eritêmatovesiculosas ou eritêmato-vésico-secretantes ou eritêmato-secretante-infiltrativaliquenificadas. Sendo o prurido um sintoma constante e de intensidade variável. ${ }^{13}$

Os alérgenos de contato são moléculas químicas não proteicas, de baixo peso molecular (menor que 500 daltons) e necessitam ligar-se a uma proteína na epiderme, para gerar um novo determinante antigênico, ${ }^{6,14}$ induzindo os queratinócitos epidérmicos ativados a liberar citocinas pró-inflamatórias. ${ }^{15}$ Os alérgenos químicos são haptenos e, como tais, são incapazes de estimular diretamente uma resposta imune. Assim, a imunogenicidade é adquirida com a formação de conjugados estáveis do hapteno com uma proteína, por ligações covalentes. O hapteno conjugado é reconhecido e processado para posterior apresentação ao sistema imune, ${ }^{10}$ muitos são lipofílicos, o que os permite atravessar a barreira córnea. A sensibilização aos íons metálicos, como o Ni2+, reage de modo diferente, gera ligações não covalentes com o complexo formado entre a proteína e o metal quelato, sendo este estável e capaz de estimular a imunidade. ${ }^{14,16}$

Mesmo com a exposição diária a diversos agentes químicos, a maioria dos indivíduos não desenvolve alergia de contato. ${ }^{10,12,17}$ Isto sugere que, sob condições fisiológicas, o sistema imunológico cutâneo possui mecanismos reguladores para evitar reações imunopatológicas aos haptenos. ${ }^{17}$

Um equilíbrio controlado entre a iniciação e a regulação negativa da resposta imunológica é importante na manutenção da homeostase imune. Quando este equilíbrio é perturbado, pela disfunção das células $\mathrm{T}$ profissionais supressoras, doenças autoimunes ou doenças alérgicas surgem como consequência de uma resposta imunológica exagerada aos antígenos não próprios. ${ }^{18}$

\subsection{Imunologia na DCA}

A imunidade inata cutânea constitui a primeira linha de defesa e também desempenha um importante papel na ativação da resposta imune adaptativa, que representa a segunda linha de defesa. ${ }^{19}$ 
Uma vez ativado, o sistema imune inato inicia a resposta inflamatória pela secreção de citocinas e quimiocinas, induzindo a expressão de moléculas de adesão para recrutar células imunes para o local da injúria e ativar a resposta adaptativa. ${ }^{20} \mathrm{~A}$ ativação do sistema imune inato pelos íons de metais ou químicos orgânicos, eventualmente, quebra a tolerância imunológica, resultando na ativação da resposta adaptativa, ou seja, a geração de um efetor de contato específico ao alérgeno e de células T de memória. ${ }^{21}$

A DCA resulta da ativação da imunidade adquirida em pessoas previamente sensibilizadas, é específica ao antígeno e leva ao desenvolvimento de células T efetoras, estas são mediadoras da inflamação cutânea, provocando o dano tecidual. 2, 6, 9, 22

Ao entrar em contato com o hapteno, os queratinócitos são ativados e produzem vários mediadores químicos, como o TNF- $\alpha$, a IL-1 $\beta$ e a prostaglandina E2, que promovem a ativação, mobilização, migração e a maturação das células dendríticas (DCs - Dendritic Cells) cutâneas. ${ }^{23}$ 24, 25, 26 Sua principal função é reconhecer e processar os antígenos externos e migrar para os linfonodos drenantes (dLNs Draining Lymph Nodes), onde apresentam os antígenos para as células T naïve. ${ }^{6}$

São necessárias duas fases para o desenvolvimento da DCA: sensibilização e elicitação, e o mecanismo regulador controla a reação inflamatória. ${ }^{6,25,27}$

A fase de sensibilização (fase aferente ou fase de indução) ocorre após semanas ou meses de exposições repetidas do contato da pele com o sensibilizante, gerando células T específicas ao hapteno nos dLNs. ${ }^{28,29}$ Os complexos formados entre o hapteno e uma proteína são captados e processados pelas células dendríticas dérmicas (dDCs Dermal Dendritic Cells), estas migram para os dLNs, onde em sua área para-cortical têm origem os linfócitos T CD8+ e CD4+ específicos ao antígeno, ${ }^{1,30}$ diferenciando-se nos efetores T helper 1 (Th1), T helper 17 (Th17) e linfócitos T citotóxicos (CTLs Cytotoxic T Lymphocytes). Esta fase ocorre em um período de 10 a 15 dias. ${ }^{6,14,16,31}$

$\mathrm{Na}$ fase de elicitação (fase eferente ou fase efetora), a reexposição ao mesmo hapteno leva ao recrutamento para a pele dos linfócitos T específicos de memória Th1, Th17 e CTLs. ${ }^{28,32,33}$ Ao mesmo tempo, desenvolvem-se as células T CD4+ reguladoras (Tregs), inibindo o processo inflamatório da DCA e mediando a tolerância nos indivíduos não alérgicos. ${ }^{14,16}$ Uma avaliação sequencial do infiltrado inflamatório da DCA demonstrou que os linfócitos encontrados no início do processo são linfócitos $\mathrm{T}$ CD8+ citotóxicos tipo 1 produtores de IFN- $\gamma(\mathrm{Tc} 1)$, seguidos de linfócitos T CD4+. ${ }^{6,34}$ 
A maior proporção de linfócitos T CD8+ foi encontrada após 12 horas do contato, e de linfócitos T CD4+ após 24 horas. ${ }^{6,35}$ Esta fase ocorre em um período de 24 a 72 horas, e a reação inflamatória persiste por alguns dias e se reduz pelo mecanismo regulador. ${ }^{14,16}$

Ocorre a produção e liberação de grande quantidade de INF- $\gamma$, que é o protótipo da citocina pró-inflamatória para a resposta do tipo $\mathrm{Th} 1,{ }^{36}$ estimulando outras células $\mathrm{T}$, células T Natural Killer (NK) e macrófagos a migrarem e ampliarem o processo inflamatório. ${ }^{6,29,37,38}$ A pele normal não contém as células T NK, elas são detectadas no eczema inflamatório após migrarem para a pele e representam apenas $10 \%$ do infiltrado linfocitário. Assim como os CTLs, as células NK também induzem a apoptose dos queratinócitos, pela rápida clivagem das moléculas de adesão, como as e-caderinas, levando a perda da coesão dos queratinócitos e a espongiose. ${ }^{39,40,41}$ É necessária a infiltração inicial dos neutrófilos para o subsequente recrutamento das células $\mathrm{T}$ e o desenvolvimento da inflamação, ${ }^{29}$ levando, também, à apoptose dos queratinócitos e à formação de vesículas. ${ }^{6,42,43,44}$

A magnitude e a persistência da reação inflamatória acontecem através da liberação de IFN- $\gamma$, TNF- $\alpha$ e IL-17, também chamada de IL-17A. ${ }^{17,36,45}$ As células T efetoras CD8+ e CD4+ produtoras de IL-17 (Th17) são distintas das células Tc1, sendo células efetoras fundamentais para a resposta imune. ${ }^{36,45}$ As principais ações da IL-17 são a indução de citocinas pró-inflamatórias, como IL-1, IL-6 e TNF- $\alpha$, de quimiocinas, CXCL1, CXCL2, CXCL5 e CXCL8, e de moléculas de adesão, ICAM-1 e VCAM-1, pelas células epiteliais e endoteliais, levando ao recrutamento de células inflamatórias e à interação dessas células com o epitélio. Assim, a IL-17 amplia o processo inflamatório local. ${ }^{6}$ As células Th17 são estimuladas pela IL-23, secretada pelas DCs e por macrófagos, mas são inibidas pela IL-12, implicando que diferentes mecanismos regulam o desenvolvimento e a função das células Th17. ${ }^{36}$ Apesar da evidência de que a principal célula efetora da DCA seja o linfócito T CD8+, é possível que a natureza do antígeno, e/ou a sua via de acesso, possa contribuir com a determinação do tipo celular envolvido na resposta que irá se formar. ${ }^{6,28,46}$

Na fase de resolução, as células Tregs CD4+, que compõem uma subfamília heterogênea de linfócitos T (Treg CD4+CD25+Foxp3+, T reguladores 1 (Tr1) e Th3), suprimem a resposta imune pela liberação de citocinas anti-inflamatórias, especialmente a IL-10, e por inativar as células T efetoras no contato célula com célula. ${ }^{6}$ É possível que as células Tregs trabalhem em um sistema de cooperação, controlando tanto a 
origem quanto a expansão das células T CD8+ nos dLNs, e sua ativação na pele. ${ }^{14,47}$ Elas podem suprimir a ativação, proliferação e funções efetoras de diversas células, como CD4+, CD8+, NK e as células apresentadoras de antígenos (APCs - AntigenPresenting Cells). ${ }^{48}$

Os linfócitos T CD4+ periféricos dos indivíduos não alérgicos expressam maior quantidade de IL-10 e menor de IFN- $\gamma$ do que nos pacientes alérgicos. Portanto, indivíduos não alérgicos apresentam maior quantidade de células $\operatorname{Tr} 1$ específicas ao hapteno no sangue, que também podem ser encontradas nas lesões cutâneas da DCA, onde modulam o término do processo alérgico. ${ }^{2,6,9,17,36}$

As Tregs capazes de circular para os dLNs possuem um potencial de remigrar para a pele, ${ }^{25}$ apoiando a hipótese de que a pele pode representar um órgão linfoide, onde as atividades das células $\mathrm{T}$ de memória são moduladas pelas Tregs. ${ }^{49}$

O número de Tregs cutâneas aumenta significativamente durante o processo inflamatório, sugerindo que possuem uma ação supressiva no local inflamado, desempenhando um importante papel no término da reação inflamatória na DCA e no controle das respostas imunes sistêmicas. ${ }^{25,47}$

\subsection{Imunologia na DCA ao Ni2+}

Apesar de o contato da pele com o $\mathrm{Ni2}+$ ser muito comum, e muitas pessoas estarem igualmente expostas, nem todas desenvolvem sensibilização a este íon metálico haptênico, que é responsável pela manifestação de eczemas cutâneos. ${ }^{4}, 10$

$\mathrm{O} \mathrm{Ni2}+$ deposita-se sobre a pele e no estrato córneo é quelado por proteínas e aminoácidos, permeando para as camadas mais profundas da epiderme. A capacidade de penetração cutânea está associada à oxidação pelo suor, que libera uma maior quantidade de íons, e à integridade da pele, penetrando mais facilmente a pele danificada do que a intacta. ${ }^{50,51}$ A sua difusão é lenta, sendo esta passagem principalmente intercelular; e, após atravessar o estrato córneo, as taxas de difusão aumentam. $^{51}$

O Ni2+ liberado por várias ligas metálicas ao penetrar a pele ativa as células epiteliais, que produzem citocinas ou quimiocinas seguido de respostas imunes hiperreativas que envolvem a ativação de células T e APCs. ${ }^{26}$ 
A DCA, após a reexposição ao Ni2+, é uma forma de alergia de contato categorizada como hipersensibilidade tipo IV ou tardia, envolvendo a proliferação de células $\mathrm{T}$ específicas ao $\mathrm{Ni2}+\mathrm{e}$ a liberação de citocinas, que se inicia quando os haptenos penetram na pele e modificam suas proteínas estruturais. ${ }^{10,26,52,53}$ Tais proteínas alteradas são percebidas como estranhas, são capturadas e transportadas pelas APCs para os dLNs, onde apresentam os haptenos às células T naïve. ${ }^{26,30,38}$ Os linfócitos $\mathrm{T}$ específicos ao Ni2+, através dos receptores de células T (TCR - T-Cell Receptors), em sua superfície externa, ${ }^{54}$ reconhecem os antígenos apresentados pelas moléculas do complexo principal de histocompatibilidade (MHC - Major Histocompatibility Complex), na superfície das APCs, sofrendo ativação e expansão clonal. $^{32,38,55}$

As DCs estão entre as APCs profissionais mais importantes para iniciar a resposta primária dos linfócitos T. Porém, vários tipos de células cutâneas podem servir como APCs para as células T de memória e as T efetoras durante a fase de elicitação da resposta imune cutânea, incluindo as células endoteliais, fibroblastos e queratinócitos. Entretanto, um número significativo de células $\mathrm{T}$ específicas ao $\mathrm{Ni2}+$, isoladas a partir de indivíduos alérgicos, pode ser ativado pelo Ni2+ na ausência das APCs profissionais. ${ }^{30} \mathrm{O} \mathrm{Ni} 2+$ pode ativar diretamente o receptor Toll-like 4 (TLR4 - Toll-Like Receptor 4) humano, induzindo sua dimerização e sinalização inflamatória (via fator nuclear- $\kappa \mathrm{B}(\mathrm{NF}-\kappa \mathrm{B}-$ Nuclear Factor- $\kappa B)$ ), culminando na produção de citocinas e quimiocinas pró-inflamatórias, ${ }^{21,} 56$ resultando em uma eficiente sensibilização e elicitação, indicando, um papel essencial do TLR4 na DCA ao Ni2+. ${ }^{25,57}$

A análise da produção de citocinas, pelas células $\mathrm{T}$ específicas ao $\mathrm{Ni2}+$ demonstrou um perfil misto de citocinas. ${ }^{58,59} \mathrm{E}$ a resposta in vitro foi demonstrada envolvendo a ativação de células $\mathrm{T}$ específicas ao $\mathrm{Ni2}+$, seguida da proliferação e indução de citocinas do tipo Th1/Tc1 (IL-2 e IFN- $\gamma$ ), Th2/Tc2 (IL-4, IL-5, IL-9 e IL-13), Th17/Tc17 (IL-17) e de citocinas reguladoras, como a IL-10. ${ }^{10,53,54,59}$

Os linfócitos T CD8+ específicos ao Ni2+ estão diretamente correlacionados à expressão do eczema de contato pelo Ni2+, enquanto os linfócitos T CD4+ específicos têm função reguladora via liberação de IL-10. ${ }^{2,17,22,53}$ Os indivíduos alérgicos ao Ni2+ apresentam linfócitos T CD8+ específicos; e as células T CD4+ específicas ao Ni2+ são encontradas em indivíduos alérgicos e não alérgicos, diferindo apenas na maior proporção de células T supressoras, produtoras de IL-10, no grupo não alérgico. ${ }^{6, ~ 55,60}$ 
Um estado não alérgico de um indivíduo não necessariamente resulta de uma falta de contato com o antígeno, mas é uma consequência da supressão ativa das células T efetoras específicas ao antígeno, pelas células Tregs CD4+ secretoras de IL-10, sendo, estas, essenciais para suprimir a reação inflamatória nos indivíduos alérgicos, através do bloqueio das DCs. ${ }^{32,44}$

\subsection{Níquel}

O metal níquel, quando comparado com outros materiais, oferece melhor resistência à corrosão, melhor enrijecimento, resistência a altas e baixas temperaturas e tem amplas propriedades eletrônicas e magnéticas. ${ }^{61,62}$ Ele auxilia outros metais a fazerem o mesmo, quando adicionado às suas ligas ou revestindo-os. ${ }^{63}$ Está presente em várias ligas metálicas, incluindo o ouro, a prata, a solda, os banhos de ouro e o aço inoxidável (contém de $8 \%$ a $12 \%$ de níquel). ${ }^{63,}{ }^{64}$ Foi purificado por Baron Axel Cronstedt em 1751, e em 1888, Ludwig Mond encontrou uma maneira fácil de extraí-lo, desde então, vem sendo amplamente utilizado. As reações aos sais de níquel (“coceira de níquel”) foram descritas por Blaschko em 1889 e por Rambousek em 1908, em banhos de níquel. ${ }^{63}$

No início do século 20, a DCA causada pelo Ni2+ era observada em mãos e antebraços de trabalhadores da indústria de galvanização. Na segunda parte do século 20, a exposição foi causada pelo uso de vários tipos de adereços metálicos. ${ }^{61,65,66,67,68}$ A associação entre eczema de mãos e a DCA ao Ni2+ é decorrente da exposição ocupacional, sem regulamentação, em várias profissões que lidam diretamente com objetos de metais, como costureiras, cabeleireiras, carpinteiros etc. ${ }^{65,69}$

A epidemia ao Ni2+ iniciou em 1950-1960, com um número crescente de pacientes femininas que tiveram erupções cutâneas de eczemas. Nos anos 1970-1980, a liberação do Ni2+ pelos adereços de roupas resultou em eczemas em ambos os sexos; e, na década de 1980, a popularização da perfuração de orelhas e a utilização de adornos folheados por Ni2+ levaram ao surgimento de eczemas em uma grande proporção de mulheres. ${ }^{70}$

O Ni2+ é o principal causador de DCA no Brasil e nos países industrializados, predominando no sexo feminino e em pacientes jovens, podendo estar relacionada ou 
não à profissão, uma vez que há atividades, no ambiente de trabalho ou no contexto doméstico, que expõem com mais frequência os indivíduos ao Ni2+. ${ }^{71,72,73,74}$

Apesar de ser rara na população infantil, a DCA é atualmente reconhecida como um problema crescente, e o Ni2+ tem recebido muita atenção por ser o agente mais comum de sensibilização. $\mathrm{O}$ aumento em sua freqüência, especialmente em mulheres e crianças, sugere uma relação de exposição precoce na infância. ${ }^{75}$ Assim, sua exposição é difícil de ser prevenida por estar presente em vários produtos, como, por exemplo, adereços de vestuários, óculos, bijuterias, chaves, moedas, utensílios domésticos, ferramentas, tintas, telefones celulares, fones de ouvido, esmaltes, cosméticos, tecidos estampados, tinturas de cabelos, materiais odontológicos, entre outros. ${ }^{26,63,75} \mathrm{O} \mathrm{Ni2+}$ também pode ser encontrado em alguns medicamentos, como os polivitamínicos, e em alguns alimentos, como: chocolate, gordura hidrogenada, feijão, nozes, ervilhas secas e cereais, contribuindo para a sensibilização. ${ }^{63,76}$ 


\section{OBJETIVOS}

\subsection{Objetivo geral}

O presente trabalho teve como objetivo o estudo de pacientes alérgicos ao Ni2+, utilizando a técnica de imuno-histoquímica para análise das citocinas TNF- $\alpha$, INF- $\gamma$, IL-2, IL-4, IL-10, IL-13, IL-17 e IL-23, que atuam na DCA ao Ni2+.

\subsection{Objetivo específico}

Estas citocinas foram selecionadas para tentar identificar a prevalência de um ou mais subtipos de células $\mathrm{T}(\mathrm{Th} / \mathrm{Tc})$, tanto no eczema crônico, desencadeado pelo contato cotidiano do paciente com o Ni2+, quanto no eczema agudo, provocado pelo teste de contato (TC) com o sulfato de níquel (NiSO4). 


\section{MÉTODOS}

\subsection{Casuística e característica da pesquisa}

Esta pesquisa foi um estudo observacional, não controlado, prospectivo, não randomizado e não cego, conduzido no período de abril/2013 a abril/2014, onde foram avaliados 20 pacientes com história pregressa de DCA ao Ni2+, apresentando eczema crônico pelo contato com o Ni2+. O grupo analisado constituiu-se de 17 mulheres e três homens, com faixa etária entre 22 e 75 anos (idade mediana de 46 anos). A captação dos pacientes ocorreu no Serviço de Dermatologia do Hospital das Clínicas/Universidade Federal de Goiás (HC/UFG).

\subsection{Critérios de inclusão}

a) sexo: masculino ou feminino;

b) faixa etária: maiores de 18 anos;

c) presença de eczema crônico pelo Ni2+ fora da área de fixação do TC, tronco posterior;

d) ausência de eczema agudo pelo Ni2+, ou de outra etiologia, em qualquer área do corpo;

e) ausência de lesões cutâneas (inflamatórias ou não inflamatórias) no tronco posterior;

f) não ter utilizado corticosteróides tópico ou sistêmico, até três semanas antes da realização do $\mathrm{TC}$;

g) não ter exposto previamente o tronco posterior ao sol, até duas semanas antes da realização do TC;

h) não ter histórico de atopia (prurido crônico, rinite, asma e histórico familiar de atopia). 


\subsection{Critérios de exclusão}

a) algum evento adverso após a fixação do TC (Anexo A);

b) retirada do TC antes de 48 horas da sua fixação;

c) TC que foram molhados;

d) grávidas e lactantes;

e) recusa do paciente em proceder à tricotomia do tronco posterior, caso fosse necessário;

f) paciente que se sentisse inseguro para a realização do TC, mesmo após a assinatura do TCLE (Termo de Consentimento Livre e Esclarecido) e das orientações relativas ao TC.

\subsection{Testes de contato (TC)}

Foram realizados TC, utilizando-se a Bateria Padrão Brasileira, Patchkit Standard New Generation ${ }^{\circledR}$, (padronizada pelo Grupo Brasileiro de Estudo em Dermatite de Contato (GBEDC)), composta por 30 substâncias, fixados na pele sã do tronco posterior dos pacientes (Anexo B). ${ }^{13,77}$

As substâncias foram colocadas em contensores (câmaras de alumínio do tipo Finn Chamber® (Epitest Ltd, Finland)) fixados em uma fita adesiva (cada fita adesiva possuia 10 câmaras côncavas de alumínio, de oito mm de diâmetro).

Após a fixação do TC o paciente foi orientado a não molhar o local e retornar ao HC/UFG após 48 horas, quando este foi retirado e realizada a primeira leitura. Após 96 horas realizou-se a segunda leitura, com a observação das orientações impressas relacionadas à(s) substância(s) positiva(s).

A montagem, fixação e as duas leituras dos TC foram realizadas por um único examinador.

Os critérios de leitura adotados foram os estabelecidos pelo International Contact Dermatitis Research Group (ICDRG):

a) negativo (-);

b) duvidoso (?); 
c) positivo fraco (+): discreto eritema com algumas pápulas;

d) positivo forte $(++)$ : eritema, pápulas e vesículas;

e) positivo muito forte $(+++)$ : intenso eritema, pápulas e vesículas confluentes. ${ }^{13,78}$

\subsection{Biópsia}

Foram realizadas duas biópsias de pele em cada um dos 20 pacientes, sendo a primeira no local do eczema crônico, pelo contato cotidiano do paciente com o $\mathrm{Ni2}+$, antes da aplicação do TC; e a segunda no local do eczema agudo, provocado pelo TC com o NiSO4, 48 horas após sua fixação nas leituras positivo forte (++) ou positivo muito forte $(+++)$. Foram colocadas em formol a $10 \%$ e enviadas para os exames de histopatologia e imuno-histoquímica, totalizando 40 biópsias.

\subsection{Imuno-histoquímica}

A técnica de imuno-histoquímica foi realizada para as citocinas: fator de necrose tumoral alfa (TNF- $\alpha$ ), interferon gama (INF- $\gamma$ ) e interleucinas (IL-2, IL-4, IL-10, IL-13, IL-17 e IL-23), nas 160 amostras de eczema agudo e 160 de eczema crônico, perfazendo um total de 320 amostras.

As técnicas de imuno-histoquímica para as ILs e o INF- $\gamma$ foram realizadas pelo Departamento de Patologia/INGOH (Instituto Goiano de Oncologia e Hematologia), Goiânia-GO; e o TNF- $\alpha$ pela FM/USP/Departamento de Patologia/Laboratório da Disciplina de Patologia e Moléstias Transmissíveis, São Paulo-SP.

\subsubsection{Coleta e preparação do material}

As 320 amostras, cortes de tecido fixado em formol e impregnado de parafina, com espessura de no máximo quatro $\mu \mathrm{m}$, foram montadas em lâminas de microscópio (DAKO FLEX IHC Microscope Slides (referência K8020)), utilizando-se o banho-maria com água destilada a uma temperatura de $50{ }^{\circ} \mathrm{C}$. Além da amostra, foi colocado na mesma lâmina o tecido-controle para validar a reação e manter o padrão de qualidade. 
As lâminas passaram pela estufa a $60^{\circ} \mathrm{C}$ por uma hora, o que garantiu a aderência dos cortes nas lâminas e a drenagem da água que se encontrava debaixo dos cortes.

\subsubsection{Procedimentos de pré-tratamento}

Consistiram na desparafinização, reidratação e recuperação antigênica induzida pelo calor nas amostras fixadas em formol e impregnadas de parafina. Esta etapa ocorreu no DAKO PT Link.

Foi realizada uma diluição de 1:50 (1500 ml de água destilada e $30 \mathrm{ml}$ da solução EnVision ${ }^{\mathrm{TM}}$ FLEX Target Retrieval Solution Low pH - tampão citrato concentrado 50x, pH 6,1) em um dos tanques do PT Link. As lâminas são colocadas no tanque pré-aquecido $\left(85^{\circ} \mathrm{C}\right)$ e incubadas por 20 minutos a $95^{\circ} \mathrm{C}$, após retornarem à temperatura de $85^{\circ} \mathrm{C}$ foram retiradas e lavadas em um tanque com EnVision ${ }^{\mathrm{TM}}$ FLEX Wash Buffer (20x) diluído, por um a cinco minutos. O EnVision ${ }^{\mathrm{TM}}$ FLEX Wash Buffer (20x) é uma solução salina com tampão TRIS com Tween 20 de pH 7,6 e foi diluído usando $50 \mathrm{ml}$ para cada litro de água.

Esta etapa de pré-tratamento foi utilizada para todos os anticorpos exceto a IL-10, na qual a recuperação se deu através de uma enzima proteolítica, a Proteinase K.

\subsubsection{Padronização dos títulos}

Os títulos das imuno-histoquímicas foram padronizados a partir das referências indicadas nas bulas dos reagentes, e foram repicados (diluindo-se ou concentrando-se), até chegarem a um padrão de maior nitidez. Cada reagente foi realizado em um único dia, bem como o caso controle externo (tecido indicado na bula). Assim, cada lâmina possuía a amostra e o tecido externo.

\subsubsection{Procedimento de coloração}

Ocorreu no DAKO Autostainer Link 48, sistema concebido para automatizar métodos de coloração manual utilizados na rotina da imuno-histoquímica, permitindo a transferência de protocolos da bancada para as estações de trabalho. 
Etapas do procedimento de coloração:

a) lavagem: com o tampão EnVision ${ }^{\mathrm{TM}}$ FLEX Wash Buffer diluído 1:20;

b) bloqueio da peroxidase endógena: utilizado em cada zona da lâmina $150 \mu \mathrm{l}$ do reagente EnVision ${ }^{\text {TM }}$ FLEX Peroxidase-Blocking (referência SM801) e incubado por cinco a sete minutos. Esta etapa inativa uma enzima existente no tecido/célula, que poderia reagir com outro substrato interferindo na reação;

c) lavagem: com o tampão EnVision ${ }^{\mathrm{TM}}$ FLEX Wash Buffer diluído 1:20;

d) bloqueio de proteínas: utilizado em cada zona da lâmina $150 \mu$ l (Protein Block Serum - Free (referência X0909)), para reduzir a marcação de fundo, e incubado por 15 minutos. Seguido de air blow (sopro). Foi aplicado apenas para a IL-10;

e) anticorpo primário: realizada diluição utilizando diluente redutor de fundo DAKO Antibody Diluent with Background Reducing Components (referência S3022). A diluição foi específica para cada anticorpo - IL-2 1:500, IL-4 1:1000, IL-10 1:15000, IL-13 1:800, IL-17 1:100, IL-23 1:100, IFN- $\gamma$ 1:500. O tempo de incubação do anticorpo foi de 20 a 30 minutos. O TNF- $\alpha$ foi diluído em BSA $1 \%$;

f) lavagem: duas vezes com o tampão EnVision ${ }^{\mathrm{TM}}$ FLEX Wash Buffer diluído 1:20;

g) linker: reagente secundário que amplifica o sinal do anticorpo primário. Foram utilizados $150 \mu \mathrm{l}$ de linker (EnVision ${ }^{\mathrm{TM}}$ FLEX + Mouse (referência 804)) em cada zona da lâmina e incubados por 15 minutos. Foi aplicado para IL-4, IL-13, IL-17 e IL-23;

h) lavagem: duas vezes com o tampão EnVision ${ }^{\mathrm{TM}}$ FLEX Wash Buffer diluído 1:20;

i) polímero: utilizado em cada zona da lâmina $150 \mu \mathrm{l}$ do reagente EnVision ${ }^{\mathrm{TM}}$ FLEX/HRP e incubado por 15 a 20 minutos. Este reagente consiste em uma estrutura base de dextrano à qual foi associado um vasto número de moléculas de peroxidase (HRP) e moléculas de anticorpos secundários. Utilizou-se uma química exclusiva para a reação de associação, que permite a ligação de, no máximo, 100 moléculas de HRP e de até 20 moléculas de anticorpo por estrutura base; 
j) lavagem: duas vezes com o tampão EnVision ${ }^{\mathrm{TM}}$ FLEX Wash Buffer diluído 1:20;

k) substrato-cromógeno: composto por dois componentes, o EnVision ${ }^{\mathrm{TM}}$ FLEX DAB + Chromogen (referência DM827), uma solução de diaminobenzidina (DAB) concentrada, e EnVision ${ }^{\mathrm{TM}}$ FLEX Substrate Buffer (referência SM803) contendo peróxido de hidrogênio. Antes de utilizá-la, a solução EnVision $^{\mathrm{TM}}$ FLEX DAB + Chromogen foi diluída em tampão EnVision ${ }^{\mathrm{TM}}$ FLEX Substrate Buffer (uma gota de DM827 para cada ml de SM803). O sistema de substrato produz um produto final castanho vivo no local do antígeno alvo. Utilizaram-se $300 \mu 1$ de cromógeno em cada zona da lâmina e incubação por três a cinco minutos;

1) lavagem: água destilada e com o tampão EnVision ${ }^{\mathrm{TM}}$ FLEX Wash Buffer diluído 1:20;

m)contra coloração: utilizados $150 \mu \mathrm{l}$ do reagente EnVision ${ }^{\mathrm{TM}}$ FLEX Hematoxylin (Link) (referência 806) em cada zona da lâmina e incubação por cinco minutos. Este reagente de coloração histológica é adequado para a visualização dos núcleos em cortes de tecido e as preparações de células. Este produto não contém álcool, sendo adequado para utilização com todos os cromógenos utilizados na imuno-histoquímica;

n) lavagem: duas vezes com água destilada e uma vez com o tampão EnVision $^{\mathrm{TM}}$ FLEX Wash Buffer diluído 1:20, de modo alternado. ${ }^{79,80}$

Os procedimentos de coloração individualizados para cada anticorpo encontramse no Anexo C.

\subsection{Quantificação das reações de imuno-histoquimica}

As 320 lâminas (160 do eczema crônico e 160 do eczema agudo) submetidas à técnica de imuno-histoquímica foram analisadas quantitativamente, considerando a área de oito campos fotografados em fotomicroscópio com objetiva de 40x, e as áreas imunomarcadas com as células inflamatórias foram observadas em cada um dos campos estudados. 
Os campos para análise foram obtidos por meio de fotografia da derme papilar/superior, onde havia maior concentração de células inflamatórias. Foi utilizada a câmera AxioCam MR3 acoplada ao microscópio Zeiss e com o programa AxioVision 4.8 em objetiva de 40x. As análises prosseguiram com o programa Image ProPlus 4, onde a área imunomarcada foi medida através da intensidade da coloração da reação de imuno-histoquímica e a área do campo foi aferida com o método de medição do programa, sendo excluídas as células da epiderme e/ou anexos cutâneos, quando existentes na imagem. Todas as áreas foram mensuradas em $\mu \mathrm{m}^{2}$.

Os dados obtidos do programa foram tabulados em planilha do Microsoft Excel 2007, relacionando a área imunomarcada com a área estudada dos campos, obtendo-se uma relação em porcentagem entre as áreas.

\subsection{Análise estatística}

As citocinas estudadas apresentaram uma distribuição de probabilidade empírica assimétrica à esquerda, com valores extremos. Por essa razão, o melhor indicador para resumir os dados foi a mediana. Foram utilizados os testes de Shapiro-Wilks (que confirmou que não existia evidência na amostra de que os dados provinham de uma distribuição de probabilidade normal) ${ }^{81}$ e o teste não paramétrico de Mann-Whitney (que verificou se a prevalência de cada uma das citocinas era similar entre os eczemas crônico e agudo, através da comparação de suas medianas). ${ }^{82,83}$ Os resultados foram considerados estatisticamente significativos para um erro do tipo I, alfa, igual a 5\%.

Para a análise dos dados utilizou-se o software estatístico STATA versão 13.

As técnicas estatísticas detalhadas encontram-se no Anexo D.

\subsection{Aprovação do estudo}

Este estudo foi aprovado pelo Comitê de Ética em Pesquisa do Hospital das Clínicas da Universidade Federal de Goiás (CEP/HC/UFG) e pelo Comitê de Ética em Pesquisa da Faculdade de Medicina da Universidade de São Paulo (CEP/FMUSP). 


\section{RESULTADOS}

O estudo foi realizado utilizando a técnica de imuno-histoquímica para oito citocinas, em 20 pacientes com DCA ao Ni2+, tanto nas amostras de eczema crônico, desencadeado pelo contato cotidiano do paciente com o Ni2+, quanto no agudo, após 48 horas da fixação do TC. Apenas três amostras foram excluídas devido a algum tipo de falha técnica, como, por exemplo, o descolamento dos cortes de pele da lâmina. As amostras coradas revelaram resultados positivos para as citocinas TNF- $\alpha$, INF- $\gamma$, IL-2, IL-4, IL-10, IL-13, IL-17 e IL-23 (Figura 1, Tabela 1).
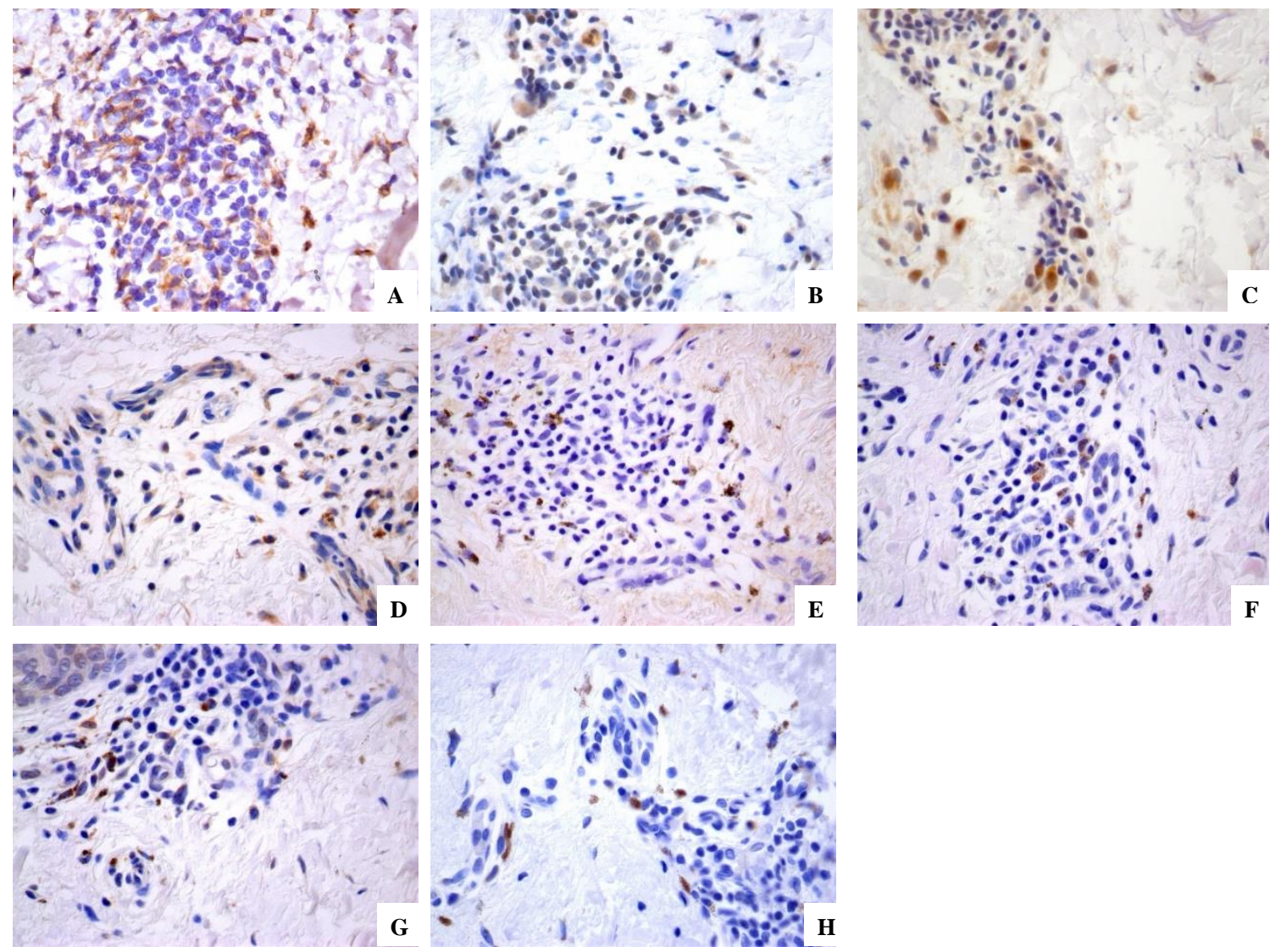

FONTE: Dados coletados pela pesquisadora.

Figura 1 - Imuno-histoquímica. As amostras coradas revelaram resultados positivos para as citocinas: A: TNF- $\alpha$, B: INF- $\gamma$, C: IL-2, D: IL-4, E: IL-10, F: IL-13, G: IL-17 e H: IL-23. Aumento de 400x 
Tabela 1 - Análise quantitativa das reações de imuno-histoquímica de oito citocinas (IFN- $\gamma$, IL-2, IL-4, IL-10, IL-13, IL-17, IL-23 e TNF- $\alpha$ ), em 320 amostras (160 do eczema crônico e 160 do eczema agudo, ocasionados pelo níquel)

\begin{tabular}{|c|c|c|c|c|c|c|c|c|c|}
\hline $\mathbf{N}$ & Tipo de eczema & IFN- $\gamma$ & IL-2 & IL-4 & IL-10 & IL-13 & IL-17 & IL-23 & TNF- $\alpha$ \\
\hline \multirow{2}{*}{1} & Eczema cr & $0,737 \%$ & $0,950 \%$ & $0,21736 \%$ & $0,0000 \%$ & $0,32880 \%$ & $0,2097 \%$ & $0,0506 \%$ & $0,0000 \%$ \\
\hline & Eczema ag & $0,468 \%$ & $0,356 \%$ & $0,11655 \%$ & $0,0000 \%$ & $0,01192 \%$ & $0,3323 \%$ & $0,1853 \%$ & $0,1880 \%$ \\
\hline \multirow{2}{*}{2} & Eczema cr & $0,534 \%$ & $0,342 \%$ & $3,13765 \%$ & $0,0040 \%$ & $0,04453 \%$ & $1,1653 \%$ & $0,1693 \%$ & $0,0000 \%$ \\
\hline & Eczema ag & $3,952 \%$ & $0,819 \%$ & $3,20573 \%$ & $0,0378 \%$ & $0,84125 \%$ & $5,6904 \%$ & $0,4186 \%$ & $0,3678 \%$ \\
\hline \multirow{2}{*}{3} & Eczema cr & $0,108 \%$ & $1,452 \%$ & $0,32544 \%$ & $0,0000 \%$ & $0,00000 \%$ & $0,0770 \%$ & $0,0006 \%$ & $0,9725 \%$ \\
\hline & Eczema ag & $0,451 \%$ & $1,755 \%$ & $3,59343 \%$ & $0,0000 \%$ & $0,00000 \%$ & $0,2111 \%$ & $0,0664 \%$ & $0,0000 \%$ \\
\hline \multirow{2}{*}{4} & Eczema cr & $0,059 \%$ & $0,032 \%$ & $0,44645 \%$ & $0,0000 \%$ & $0,0000 \%$ & $0,1743 \%$ & $0,0000 \%$ & $0,0000 \%$ \\
\hline & Eczema ag & $0,546 \%$ & $0,771 \%$ & $0,0000 \%$ & $0,0000 \%$ & $0,08509 \%$ & $0,5510 \%$ & $0,0327 \%$ & $1,6624 \%$ \\
\hline \multirow{2}{*}{5} & Eczema cr & $0,607 \%$ & $0,909 \%$ & $0,19518 \%$ & $0,4680 \%$ & $0,22678 \%$ & $0,1789 \%$ & $0,2823 \%$ & $0,6662 \%$ \\
\hline & Eczema ag & $0,882 \%$ & $1,682 \%$ & $0,04640 \%$ & $0,0000 \%$ & $0,00074 \%$ & $0,7116 \%$ & $0,4925 \%$ & $2,1741 \%$ \\
\hline \multirow{2}{*}{6} & Eczema cr & $0,604 \%$ & $1,104 \%$ & $1,61041 \%$ & $0,3669 \%$ & $0,44522 \%$ & $0,7280 \%$ & $0,4121 \%$ & $1,4677 \%$ \\
\hline & Eczema ag & $1,308 \%$ & $1,119 \%$ & $0,47994 \%$ & $0,3017 \%$ & $0,25747 \%$ & $0,9331 \%$ & $0,7674 \%$ & $0,2112 \%$ \\
\hline \multirow{2}{*}{7} & Eczema cr & $0,382 \%$ & $0,869 \%$ & $0,34805 \%$ & $0,2047 \%$ & $0,47952 \%$ & $1,6346 \%$ & $0,0494 \%$ & $1,4763 \%$ \\
\hline & Eczema ag & $0,047 \%$ & $0,046 \%$ & $0,00638 \%$ & $0,0107 \%$ & $0,0127 \%$ & $0,0160 \%$ & $0,0690 \%$ & $0,1836 \%$ \\
\hline \multirow{2}{*}{8} & Eczema cr & $0,118 \%$ & $0,884 \%$ & $0,37876 \%$ & $0,0000 \%$ & $0,0000 \%$ & $0,3121 \%$ & $0,0030 \%$ & $0,0000 \%$ \\
\hline & Eczema ag & $0,021 \%$ & $0,060 \%$ & $0,01825 \%$ & $0,0250 \%$ & $0,0000 \%$ & $0,3204 \%$ & $10,5497 \%$ & $0,0000 \%$ \\
\hline \multirow{2}{*}{9} & Eczema cr & $0,148 \%$ & $0,325 \%$ & $0,22387 \%$ & ----- & $0,16626 \%$ & $0,2631 \%$ & $0,1423 \%$ & ----- \\
\hline & Eczema ag & $0,027 \%$ & $0,169 \%$ & $0,0000 \%$ & $0,0000 \%$ & $0,0000 \%$ & $0,0333 \%$ & $0,1206 \%$ & $2,0736 \%$ \\
\hline \multirow{2}{*}{10} & Eczema cr & $0,389 \%$ & $0,248 \%$ & $0,86027 \%$ & $0,1510 \%$ & $0,17505 \%$ & $0,2001 \%$ & $0,0967 \%$ & $1,2447 \%$ \\
\hline & Eczema ag & $0,013 \%$ & $0,713 \%$ & $1,59446 \%$ & $0,0032 \%$ & $0,0000 \%$ & $0,0911 \%$ & $0,1775 \%$ & $0,0000 \%$ \\
\hline \multirow{2}{*}{11} & Eczema cr & $0,000 \%$ & $0,197 \%$ & $0,0000 \%$ & $0,0000 \%$ & $0,0000 \%$ & $0,1429 \%$ & $0,0000 \%$ & $1,9661 \%$ \\
\hline & Eczema ag & $0,319 \%$ & $0,319 \%$ & $0,02268 \%$ & $0,0000 \%$ & $0,0000 \%$ & $0,1357 \%$ & $0,0143 \%$ & $3,1056 \%$ \\
\hline \multirow{2}{*}{12} & Eczema cr & $0,000 \%$ & $0,020 \%$ & $0,48917 \%$ & $0,0000 \%$ & $0,0000 \%$ & $0,1172 \%$ & $0,1371 \%$ & $1,1221 \%$ \\
\hline & Eczema ag & $1,773 \%$ & $0,438 \%$ & $1,64413 \%$ & $0,0000 \%$ & $0,0000 \%$ & $0,1204 \%$ & $0,2050 \%$ & $0,0000 \%$ \\
\hline \multirow{2}{*}{13} & Eczema cr & $0,035 \%$ & $0,080 \%$ & $0,04448 \%$ & $0,0000 \%$ & $0,18823 \%$ & $0,1052 \%$ & $0,0738 \%$ & $1,0274 \%$ \\
\hline & Eczema ag & $0,215 \%$ & $0,601 \%$ & $0,06427 \%$ & $0,0215 \%$ & $0,0000 \%$ & $0,1374 \%$ & $0,2862 \%$ & $0,6652 \%$ \\
\hline
\end{tabular}


conclusão Tabela 1 - Análise quantitativa das reações de imuno-histoquímica de oito citocinas (IFN- $\gamma$, IL-2, IL-4, IL-10, IL-13, IL-17, IL-23 e TNF- $\alpha$ ), em 320 amostras (160 do eczema crônico e 160 do eczema agudo, ocasionados pelo níquel)

\begin{tabular}{|c|c|c|c|c|c|c|c|c|c|}
\hline $\mathbf{N}$ & Tipo de eczema & IFN- $\gamma$ & IL-2 & IL-4 & IL-10 & IL-13 & IL-17 & IL-23 & TNF- $\alpha$ \\
\hline \multirow{2}{*}{14} & Eczema cr & $0,536 \%$ & $0,204 \%$ & $0,09632 \%$ & $0,0412 \%$ & $0,10718 \%$ & $0,1065 \%$ & $0,1261 \%$ & $0,2513 \%$ \\
\hline & Eczema ag & $0,068 \%$ & $0,265 \%$ & $0,04844 \%$ & $0,1167 \%$ & $0,02419 \%$ & $0,0696 \%$ & $0,0334 \%$ & $0,0511 \%$ \\
\hline \multirow{2}{*}{15} & Eczema cr & $0,519 \%$ & $0,221 \%$ & $0,28177 \%$ & $0,0126 \%$ & $1,29387 \%$ & $0,5373 \%$ & $0,0000 \%$ & $2,2824 \%$ \\
\hline & Eczema ag & $0,001 \%$ & $0,136 \%$ & $0,14102 \%$ & $0,0046 \%$ & $0,0000 \%$ & $0,0301 \%$ & $0,0000 \%$ & $0,0000 \%$ \\
\hline \multirow{2}{*}{16} & Eczema cr & $0,286 \%$ & $0,318 \%$ & $0,10705 \%$ & $0,1545 \%$ & $0,03365 \%$ & $0,3748 \%$ & $0,1230 \%$ & $1,2960 \%$ \\
\hline & Eczema ag & $0,116 \%$ & $0,027 \%$ & $0,02668 \%$ & $0,0000 \%$ & $0,0000 \%$ & $0,0937 \%$ & $0,0760 \%$ & $2,8711 \%$ \\
\hline \multirow{2}{*}{17} & Eczema cr & $0,187 \%$ & $0,228 \%$ & $0,04855 \%$ & $0,0207 \%$ & $0,0000 \%$ & $1,0891 \%$ & $0,0000 \%$ & $0,0000 \%$ \\
\hline & Eczema ag & $0,133 \%$ & $2,673 \%$ & $0,0000 \%$ & $0,0223 \%$ & $0,02783 \%$ & $0,1344 \%$ & $0,0274 \%$ & $0,4137 \%$ \\
\hline \multirow{2}{*}{18} & Eczema cr & $0,498 \%$ & $0,393 \%$ & $0,37860 \%$ & $0,2112 \%$ & $0,16018 \%$ & $0,4355 \%$ & $0,2590 \%$ & $0,5967 \%$ \\
\hline & Eczema ag & $0,087 \%$ & $0,144 \%$ & $0,02491 \%$ & $0,0089 \%$ & $0,00620 \%$ & $0,0757 \%$ & $0,0998 \%$ & $0,0000 \%$ \\
\hline \multirow{2}{*}{19} & Eczema cr & $0,367 \%$ & $0,940 \%$ & $0,07814 \%$ & $0,0082 \%$ & $0,00712 \%$ & $0,1361 \%$ & $0,1099 \%$ & $2,3796 \%$ \\
\hline & Eczema ag & $0,000 \%$ & $0,469 \%$ & $0,000 \%$ & $0,0217 \%$ & $0,0000 \%$ & $0,0673 \%$ & ---- & $1,5081 \%$ \\
\hline \multirow{2}{*}{20} & Eczema cr & $0,213 \%$ & $1,941 \%$ & $0,27333 \%$ & $0,0610 \%$ & $0,01930 \%$ & $0,0841 \%$ & $0,0684 \%$ & $2,8617 \%$ \\
\hline & Eczema ag & $0,082 \%$ & $0,108 \%$ & $0,01537 \%$ & $0,0490 \%$ & $0,01103 \%$ & $0,0257 \%$ & $0,0154 \%$ & $0,1261 \%$ \\
\hline
\end{tabular}

FONTE: Dados coletados pela pesquisadora.

$\mathrm{N}$ : número de casos; INF- $\gamma$ : Interferon gama; TNF- $\alpha$ : Fator de Necrose Tumoral alfa; IL: Interleucina.

Eczema cr: Eczema crônico; Eczema ag: Eczema agudo. 
As citocinas estudadas apresentaram valores heterogêneos. Esta heterogeneidade foi demonstrada pelo coeficiente de variação $(\mathrm{CV})$, um indicador da variabilidade do conjunto dos dados obtidos. As principais estatísticas descritivas para cada uma das citocinas, segundo o tipo de eczema, estão na Tabela 2.

O TNF- $\alpha$ teve prevalência maior no eczema crônico (mediana=0,97) comprando-se com o agudo (mediana=0,20), sendo a citocina que mais prevaleceu no eczema crônico (Tabela 2). Houve uma maior heterogeneidade dos valores no eczema agudo $(\mathrm{CV}=1,34)$, em comparação com o crônico $(\mathrm{CV}=0,94)$ (Tabela 2), com ausência de valores atípicos (Gráfico 1).

A prevalência do IFN- $\gamma$ foi maior no eczema crônico (mediana=0,33), em comparação com o agudo (mediana=0,12) (Tabela 2). A heterogeneidade dos valores foi maior no eczema agudo $(\mathrm{CV}=1,78)$ (Tabela 2$)$, com a presença de três valores atípicos (Gráfico 1).

Gráfico 1 - Gráfico de caixas para as citocinas TNF- $\alpha$ e IFN- $\gamma$, segundo o tipo de eczema

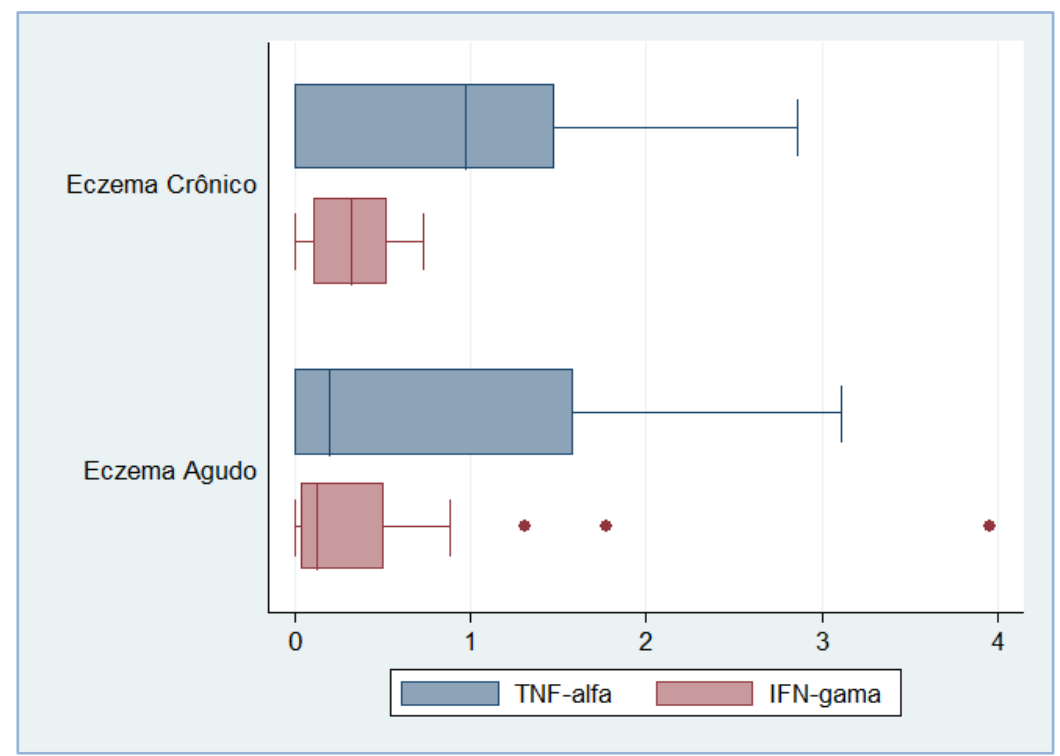

FONTE: Dados coletados pela pesquisadora. 
Tabela 2 - Estatísticas descritivas de oito citocinas (IFN- $\gamma$, IL-2, IL-4, IL-10, IL-13, IL-17, IL-23 e TNF- $\alpha$ ), avaliadas pela técnica de imunohistoquímica, nos eczemas crônico e agudo ocasionados pelo níquel, em 20 pacientes

\begin{tabular}{|c|c|c|c|c|c|c|c|c|c|}
\hline \multirow{3}{*}{ Citocina } & \multicolumn{9}{|c|}{ Tipo de Eczema } \\
\hline & \multicolumn{5}{|c|}{ Crônico } & \multicolumn{4}{|c|}{ Agudo } \\
\hline & $\mathbf{N}$ & Mínimo & Máximo & Mediana & $\mathbf{C V}$ & Mínimo & Máximo & Mediana & $\mathrm{CV}$ \\
\hline IFN- $\gamma$ & 20 & 0,00 & 0,74 & 0,33 & 0,73 & 0,00 & 3,95 & 0,12 & 1,78 \\
\hline IL-2 & 20 & 0,02 & 1,45 & 0,32 & 0,85 & 0,03 & 2,67 & 0,40 & 1,10 \\
\hline IL-4 & 20 & 0,00 & 3,14 & 0,28 & 1,51 & 0,00 & 3,59 & 0,04 & 1,97 \\
\hline IL-10 & 19 & 0,00 & 0,47 & 0,01 & 1,53 & 0,00 & 0,30 & 0,01 & 2,23 \\
\hline IL-13 & 20 & 0,00 & 1,29 & 0,08 & 1,64 & 0,00 & 0,84 & 0,00 & 3,01 \\
\hline IL-17 & 20 & 0,08 & 1,17 & 0,19 & 0,97 & 0,02 & 5,69 & 0,13 & 2,55 \\
\hline IL-23 & 20 & 0,00 & 0,41 & 0,09 & 1,05 & 0,00 & 10,55 & 0,10 & 3,33 \\
\hline TNF- $\alpha$ & 19 & 0,00 & 2,86 & 0,97 & 0,94 & 0,00 & 3,11 & 0,20 & 1,34 \\
\hline
\end{tabular}

FONTE: Dados coletados pela pesquisadora.

$\mathrm{N}$ : número de casos; CV: Coeficiente de Variação. 
A IL-2 apresentou maior prevalência no eczema agudo (mediana=0,40) do que no crônico (mediana=0,32), sendo a citocina mais prevalente no eczema agudo (Tabela 2). Também se observa uma maior heterogeneidade dos valores no eczema agudo $(\mathrm{CV}=1,10)$ (Tabela 2), com a presença de um valor atípico (Gráfico 2).

Houve uma maior prevalência da IL-4 no eczema crônico (mediana=0,28), em comparação com o agudo (mediana=0,04) (Tabela 2). Em relação à heterogeneidade dos valores, foi maior no eczema agudo $(\mathrm{CV}=1,97)$ (Tabela 2$)$, apresentando quatro valores atípicos (Gráfico 2).

Gráfico 2 - Gráfico de caixas para as citocinas IL-2 e IL-4, segundo o tipo de eczema

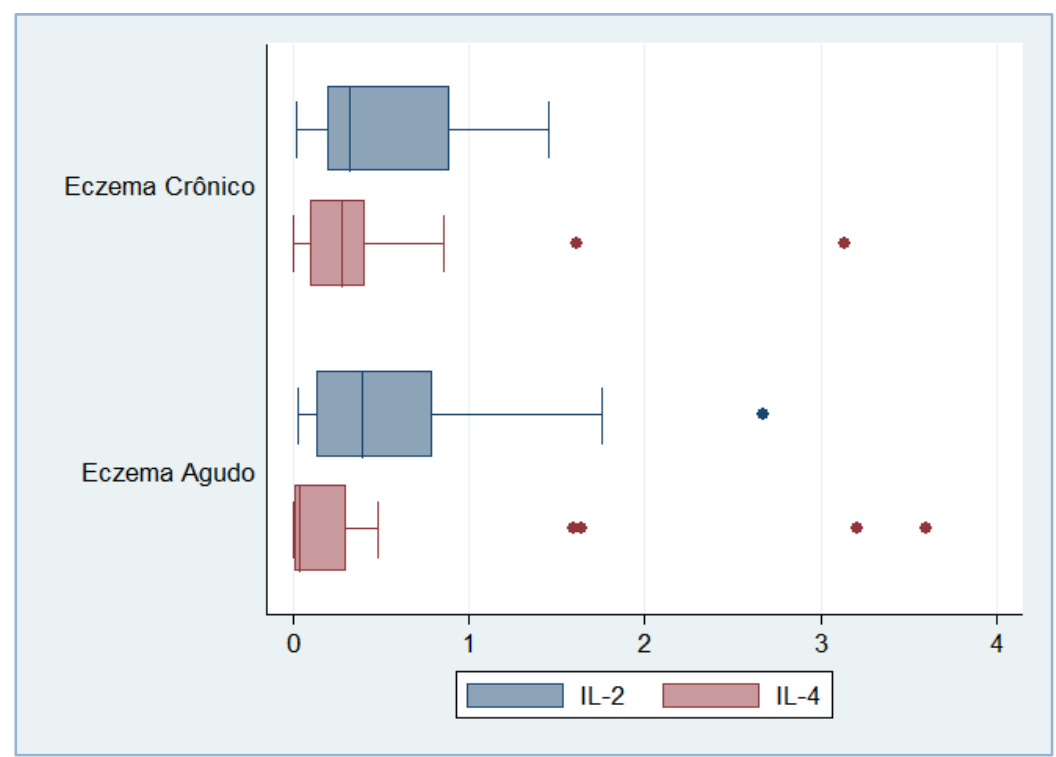

FONTE: Dados coletados pela pesquisadora.

A IL-10 apresentou prevalência similar, tanto no eczema agudo quanto no crônico (mediana $=0,01$ ) (Tabela 2). A heterogeneidade dos valores foi maior no eczema agudo ( $\mathrm{CV}=2,23)$ (Tabela 2), com a presença de dois valores atípicos (Gráfico 3).

A IL-13 teve uma maior prevalência no eczema crônico (mediana=0,08), e no eczema agudo a prevalência estimada foi muito baixa, encontrando-se próxima de zero (mediana $=0,00)$ (Tabela 2). No entanto, ocorreu uma maior heterogeneidade dos valores no eczema agudo $(\mathrm{CV}=3,01)$ (Tabela 2$)$, com a presença de três valores atípicos (Gráfico 3). 
Gráfico 3 - Gráfico de caixas para as citocinas IL-10 e IL-13, segundo o tipo de eczema

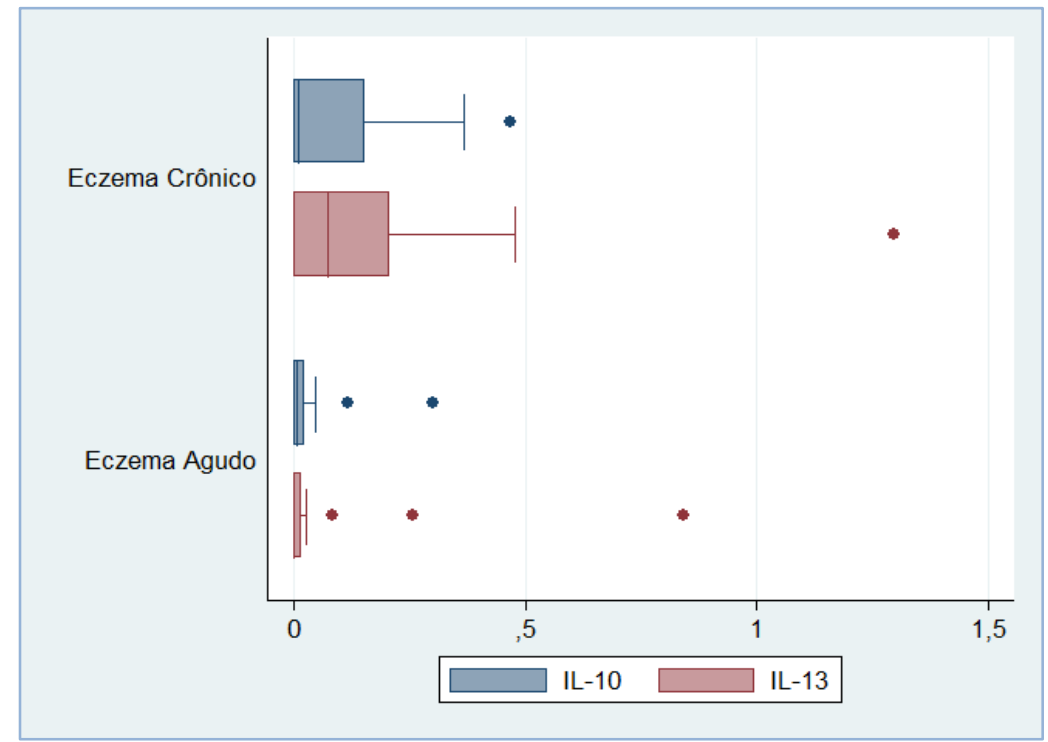

FONTE: Dados coletados pela pesquisadora.

A prevalência da IL-17 foi maior no eczema crônico (mediana=0,19) do que no agudo (mediana=0,13) (Tabela 2). A maior heterogeneidade dos valores foi no eczema agudo $(\mathrm{CV}=2,55)$ (Tabela 2), apresentando dois valores atípicos (Gráfico 4).

A IL-23 apresentou uma maior prevalência no eczema agudo (mediana=0,10), em comparação com o crônico (mediana=0,09) (Tabela 2). Também ocorreu uma maior heterogeneidade dos valores no eczema agudo $(\mathrm{CV}=3,33)$ (Tabela 2), com dois valores atípicos (Gráfico 4).

Gráfico 4 - Gráfico de caixas para as citocinas IL-17 e IL-23, segundo o tipo de eczema

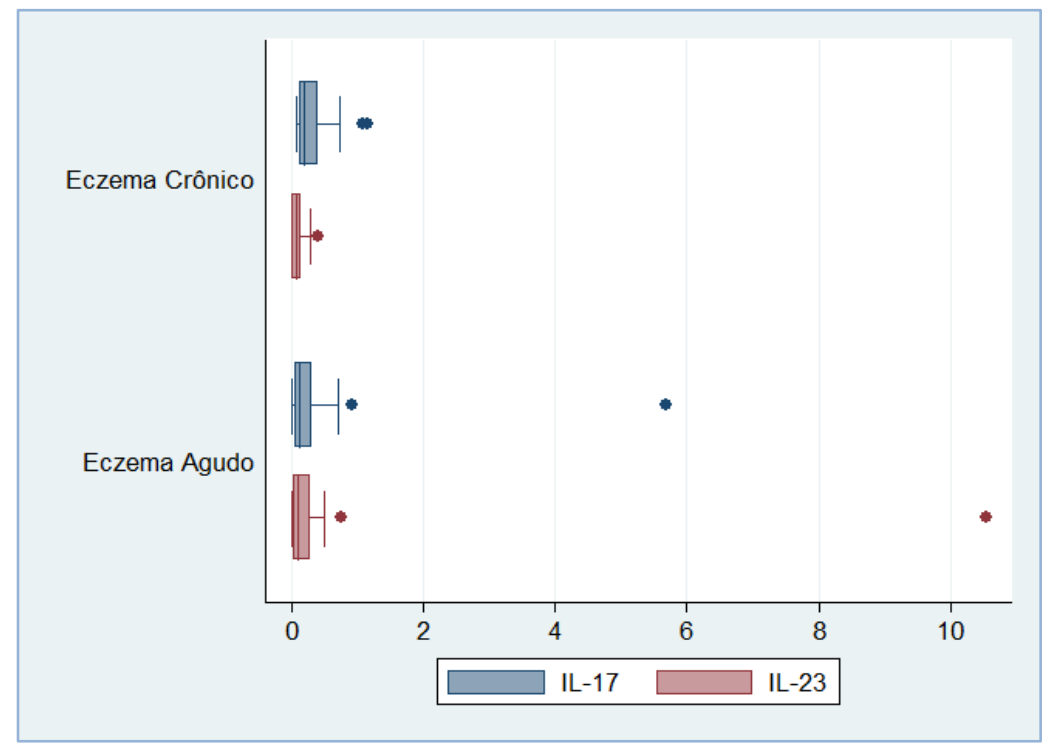

FONTE: Dados coletados pela pesquisadora. 
$\mathrm{Na}$ avaliação da suposição de distribuição de probabilidade normal para os valores dos eczemas crônico e agudo, de cada uma das citocinas estudadas, verificou-se que esta distribuição não apresentou uma forma simétrica em torno do valor médio da variável, assim, as distribuições foram assimétricas à esquerda, apresentando uma grande dispersão. Considerando um nível de significância de 0,05 ( $p$-value<0,05) observou-se que, em nenhuma das citocinas estudadas houve distribuição normal dos valores (Tabela 3).

Tabela 3 - Avaliação da suposição de distribuição de probabilidade normal para os valores de oito citocinas (IFN- $\gamma$, IL-2, IL-4, IL-10, IL-13, IL-17, IL-23 e TNF- $\alpha$ ) nos eczemas crônico e agudo ocasionados pelo níquel, para $p$-value $<0,05$ não houve distribuição normal dos valores

\begin{tabular}{cc}
\hline Variável & p-value \\
\hline IFN- $\gamma$ & 0,000 \\
IL-2 & 0,000 \\
IL-4 & 0,000 \\
IL-10 & 0,000 \\
IL-13 & 0,000 \\
IL-17 & 0,000 \\
IL-23 & 0,000 \\
TNF- $\alpha$ & 0,011 \\
\hline
\end{tabular}

FONTE: Dados coletados pela pesquisadora.

Na comparação das medianas de cada uma das citocinas nos eczemas crônico e agudo, verificou-se que, estatisticamente e para um nível de significância de 0,05 ( $p$-value $<0,05)$, as medianas da IL-4 ( $p$-value=0,03) e da IL-13 ( $p$-value=0,03) foram diferentes nos eczemas crônico e agudo. Entretanto, não foi possível estabelecer diferenças nos valores das medianas para as citocinas IFN- $\gamma$, IL-2, IL-10, IL-17, IL-23 e TNF- $\alpha$ (Tabela 4). 
Tabela 4 - Comparação das medianas de oito citocinas (IFN- $\gamma$, IL-2, IL-4, IL-10, IL-13, IL-17, IL-23 e TNF- $\alpha$ ) nos eczemas crônico e agudo ocasionados pelo níquel, para $p$-value $<0,05$ houve diferença entre as medianas

\begin{tabular}{cc}
\hline Citocina & p-value \\
\hline IFN- $\gamma$ & 0,5338 \\
IL-2 & 0,8924 \\
IL-4 & 0,0303 \\
IL-10 & 0,3546 \\
IL-13 & 0,0336 \\
IL-17 & 0,0884 \\
IL-23 & 0,2375 \\
TNF- $\alpha$ & 0,4775 \\
\hline
\end{tabular}

FONTE: Dados coletados pela pesquisadora. 


\section{DISCUSSÃO}

As citocinas são determinantes e moduladoras importantes nas patologias imunológicas, sugerindo um papel central das citocinas específicas ao antígeno na DCA. Em particular, os tipos secretados pelas células T específicas ao Ni2+ controlam a expressão da DCA ao $\mathrm{Ni} 2+.{ }^{84} \mathrm{O}$ padrão de citocinas produzido em resposta ao Ni2+ pode variar, dependendo dos vários tipos de células envolvidas (clones de células $\mathrm{T}$ específicos ao Ni2+). ${ }^{85}$ Foram encontradas, na pele com eczema de contato, diferenças no perfil de citocinas de acordo com o período de tempo de ocorrência das várias células T participantes. ${ }^{86}$

Nas reações positivas ao TC, pode ser identificada uma multiplicidade de citocinas, sugerindo que vários subtipos de células $\mathrm{T}(\mathrm{Th} / \mathrm{Tc})$ estão envolvidos na DCA, e formam o seu tipo específico de inflamação. ${ }^{25,87}$ Foi demonstrado que os linfócitos de pacientes com TC positivo a sais metálicos produzem IFN- $\gamma$ associado à Th1, bem como a IL-4 e IL-13 associada a Th2. O IFN- $\gamma$ e a IL-4 são necessários para a sensibilização e a elicitação, sugerindo que os linfócitos Th1 e Th2 atuam na DCA. ${ }^{87}$

Em um estudo comparativo de linfócitos $\mathrm{T}$ específicos ao Ni2+, demonstrou-se que um perfil de citocinas Th1 predomina entre os clones derivados do sangue periférico, enquanto que um perfil Th2 ou Th0 de citocinas ocorre entre os clones derivados da pele. ${ }^{84}$ Indivíduos alérgicos ao $\mathrm{Ni} 2+$ responderam com uma produção significativamente maior de IFN- $\gamma$, IL-2, IL-4, IL-5 e IL-13 em comparação com os controles não alérgicos. Estudos sugerem que tanto a IL-2 como o IFN- $\gamma$ são moléculas imunorreguladoras importantes envolvidas na indução da linfoproliferação pelo $\mathrm{Ni} 2+{ }^{52,84,88}$

O IFN- $\gamma$ é uma importante citocina inflamatória produzida pelas células T CD4+ e CD8+ na DCA em humanos e camundongos. No entanto, durante a última década, tornou-se evidente que outras citocinas inflamatórias, como a interleucina IL-17, podem 
ter um papel importante na resposta imune aos alérgenos de contato. A IL-17 e o IFN- $\gamma$ são efetores importantes nas reações eczematosas da DCA induzidas pelo Ni2+. ${ }^{89}$

O TNF- $\alpha$ é sintetizado principalmente por macrófagos, sendo que os queratinócitos, monócitos, neutrófilos, linfócitos T e NK também o sintetizam. É uma citocina muito sensível, ${ }^{90}$ possuindo uma vasta gama de ações pró-inflamatórias, ${ }^{91}$ estando associado à dermatite de contato alérgica e irritativa. ${ }^{12} \mathrm{O}$ TNF- $\alpha$ agrava diretamente as reações da DCA por induzir a apoptose de queratinócitos, ativa as células endoteliais vasculares a expressarem moléculas de adesão, como ICAM-1 e P/E selectina, que orientam as células $\mathrm{T}$ do sangue a transmigrarem para os tecidos, contribuindo para o processo inflamatório no local provocado pelo $\mathrm{Ni} 2+{ }^{7} \mathrm{O}$ aumento da sua secreção também é dose dependente do Ni2+. ${ }^{90}$ Em nossos dados, o TNF- $\alpha$ apresentou maior prevalência no eczema crônico do que no agudo, sendo a citocina mais prevalente no eczema crônico, como uma consequência da inflamação persistente que evolui para a cronicidade, após contatos repetidos com o Ni2+. Entretanto, esta maior prevalência no eczema crônico não foi estatisticamente significante.

A IL-2 é produzida pelas células T CD4+, atua sobre as mesmas células que a produzem, isto é, funciona como um fator de crescimento autócrino. Estimula o crescimento, diferenciação e proliferação dos linfócitos T, B (formação de anticorpos) e NK (favorece sua ação citolítica). É responsável pela expansão clonal de linfócitos específicos ao antígeno que está sendo apresentado. ${ }^{92}$ A resposta primária das citocinas envolve a IL-2, cujo nível no soro foi elevado em todos os indivíduos examinados, alérgicos ao Ni2+. O tempo também é fundamental, a IL-2 é uma citocina liberada numa fase inicial da resposta imune em pacientes alérgicos ao $\mathrm{Ni2}+{ }^{85} \mathrm{Em}$ culturas estimuladas de células mononucleares do sangue periférico de pacientes alérgicos ao Ni2+, produziram-se quantidades significativas de IL-2 com 24 horas. ${ }^{52}$ Nossos dados demonstraram que a IL-2 apresentou maior prevalência no eczema agudo do que no crônico, sendo a mais prevalente das citocinas no eczema agudo, cuja biópsia foi realizada com 48 horas da provocação com o NiSO4. Porém, esta maior prevalência no eczema agudo não foi estatisticamente significante.

Há uma resposta proliferativa de células $\mathrm{T}$ específicasao Ni2+ em indivíduos alérgicos, em contraste com os pacientes não alérgicos, e uma produção de IFN- $\gamma$ com a expressão de IL-4 e IL-13 para o Ni2+, ${ }^{54}$ indicando um padrão misto de citocinas nos indivíduos alérgicos ao $\mathrm{Ni} 2+{ }^{52}$ 
A IL-13 é uma citocina similar à IL-4, participando da resposta alérgica. É produzida principalmente pelas células T CD4+ do subconjunto Th2, e por outras células, como o linfócito NK e os mastócitos. O receptor celular que reconhece a IL-13 é capaz de ligar a IL-4 à IL-13 com alta afinidade. Isso explica o compartilhamento de efeitos biológicos entre essas duas interleucinas. ${ }^{93} \mathrm{O}$ número de células produtoras de IL-4 correlaciona-se com o número de células produtoras de IL-13, sugerindo uma sinergia entre as citocinas do tipo Th2. ${ }^{14}, 52$ A IL-13 estimula o crescimento e diferenciação de linfócitos $\mathrm{B}$, inibe a produção de citocinas pró-inflamatórias Th1 e, também, de IL-8, IL-10 e IL-12. ${ }^{93}$

O ponto do tempo também é crucial. Em culturas estimuladas de células mononucleares do sangue periférico de pacientes alérgicos ao $\mathrm{Ni} 2+$, produziram-se níveis aumentados de IL-4 com 72 horas. ${ }^{52}$ Neste estudo, as biópsias nos eczemas agudos foram coletadas com 48 horas da provocação com o NiSO4, em uma pele nunca antes penetrada pelo antígeno; e as IL-4 e IL-13 apresentaram prevalências muito baixas, provavelmente necessitariam de mais tempo para serem sintetizadas. Os dados coletados evidenciaram uma maior prevalência do IFN- $\gamma$, IL-4 e IL-13 no eczema crônico. Como este é frequentemente provocado por reexposições repetidas ao $\mathrm{Ni2+}$, estas citocinas apresentaram prevalências mais elevadas. Estas prevalências foram estatisticamente significantes para a IL-4 e IL-13, o mesmo não se aplicou para o IFN- $\gamma$.

A IL-10 foi identificada como uma potente citocina anti-inflamatória produzida pelas células T CD4+, regulando negativamente a expressão de moléculas coestimuladoras necessárias para a apresentação adequada do antígeno. Apresenta um papel regulador nas fases de sensibilização e elicitação da DCA, contribuindo para o controle da resposta imune ao $\mathrm{Ni} 2+{ }^{4}$

Os clones de células T CD4+ específicos ao Ni2+ a partir de indivíduos não alérgicos produzem níveis mais elevados de IL-10 e níveis mais baixos de IFN- $\gamma$ do que os clones CD4+ derivados daqueles com alergia ao Ni2+. Assim, a IL-10 atua para conter a atividade dos efetores CD8+ em pacientes alérgicos e previne a aquisição de sensibilização nos não alérgicos. ${ }^{24}$ Nossos dados demonstraram que a IL-10 apresentou prevalência similar nos eczemas crônico e agudo. Porém, estas prevalências foram muito baixas, em ambos os eczemas. Assim, a falta de regulação negativa das citocinas pró-inflamatórias propiciou a persistência da reação inflamatória cutânea no eczema crônico frequentemente provocado pelo Ni2+. Entretanto, não foi possível estabelecer 
uma diferença estatística das prevalências nos eczemas crônico e agudo, e, embora, as prevalências tenham sido muito próximas, devido a heterogeneidade dos valores não se pode afirmar que estatisticamente houve igualdade das prevalências.

Ao lado do IFN- $\gamma$, outras citocinas, como a IL-17, estão envolvidas na regulação de doenças alérgicas cutâneas. Com isso, a inflamação na DCA é susceptível de ser instigada e sustentada pelos efeitos pró-inflamatórios da IL-17A/IL-17F e outras citocinas produzidas pelas células Th17/Tc17 específicas aos antígenos, sendo participantes regulares nos infiltrados celulares, desempenham um papel importante na fase de elicitação da DCA. ${ }^{38,45}$ A liberação de IL-17 está correlacionada com a síntese de TNF- $\alpha$ e IL-23. ${ }^{45}$

Estudos imuno-histoquímicos realizados em biópsias de pele com 24, 48, 72 e 96 horas, após TC positivo ao NiSO4, evidenciaram que com 24 horas a IL-17 não apresentou aumento significativo. Um aumento notável foi observado com 48 e 72 horas, quando as células positivas foram evidenciadas na derme papilar. Observaram-se numerosas células IL-17+ intraepidérmicas com 96 horas, principalmente distribuídas no local da lesão tecidual intensa (espongiose epidérmica e microvesiculação), fazendo um paralelo com os sintomas clínicos da reação alérgica. ${ }^{45}$ Nossos dados demonstraram que a IL-17 teve prevalência maior no eczema crônico do que no eczema agudo. Assim, sendo um mediador pró-inflamatório, as lesões crônicas são frequentemente reagudizadas, resultando em uma reação inflamatória cutânea intensa e sustentada. Porém, esta maior prevalência no eczema crônico não foi estatisticamente significante.

A IL-23 é produzida por macrófagos e DCs, sendo importante para o desenvolvimento das funções efetoras das células $\mathrm{Th} 17,{ }^{38}$ promovendo a expressão e a manutenção da produção da IL-17 e TNF- $\alpha .{ }^{94}$ Apresenta uma função decisiva no desenvolvimento da inflamação dérmica e acantose epidérmica, desempenhando um papel fundamental na DCA. Isto foi demonstrado em camundongos deficientes em IL-23, que apresentaram reação de hipersensibilidade prejudicada. ${ }^{38}$ Nossos dados evidenciaram positividade para a IL-23, que apresentou uma maior prevalência no eczema agudo, em comparação com o eczema crônico. Entretanto, esta maior prevalência no eczema agudo não foi estatisticamente significante. 


\section{CONCLUSÃO}

A resposta proliferativa de células $\mathrm{T}$ específicasao $\mathrm{Ni2}+$ tem sido investigada em vários estudos, indicando uma multiplicidade de citocinas nos indivíduos alérgicos ao $\mathrm{Ni} 2+$.

Com a análise das citocinas TNF- $\alpha$, INF- $\gamma$, IL-2, IL-4, IL-10, IL-13, IL-17 e IL-23, nos eczemas crônico e agudo de pacientes com DCA ao Ni2+, observou-se a presença de um perfil misto de citocinas dos subtipos de células $\mathrm{T}(\mathrm{Th} / \mathrm{Tc})$, sugerindo que as respostas são expressas ao mesmo tempo. O TNF- $\alpha$, IFN- $\gamma$, IL-4, IL-13 e IL-17 tiveram prevalência maior no eczema crônico, a IL-2 e IL-23 no eczema agudo e a IL-10 apresentou prevalência similar em ambos os eczemas. Verificou-se que a maior prevalência de IL-4 e IL-13 no eczema crônico foi estatisticamente significante, porém, não foi possível estabelecer significancia estatística da maior prevalência no eczema crônico para IFN- $\gamma$, IL-17 e TNF- $\alpha$ e no eczema agudo para IL-2 e IL-23. E, devido à heterogeneidade dos valores, não se pode afirmar que estatisticamente houve igualdade das prevalências para IL-10.

Entretanto, são necessários mais estudos para uma compreensão mais ampla sobre o perfil das citocinas na DCA ao Ni2+, o que poderia levar a novas abordagens terapêuticas. 


\section{ANEXOS}

\section{Anexo A - Eventos adversos}

\section{Reações adversas aos TC}

a) exacerbação ectópica da dermatite: o TC positivo pode levar à exacerbação da dermatose pré-existente;

b) fenômeno de Köebner: o TC positivo em pacientes com psoríase ou líquen plano, pode reproduzir a dermatose no local do TC;

c) alteração de pigmentação: surgimento de hiperpigmentação ou hipopigmentação no local do TC positivo;

d) irritação periférica: ocorre na periferia do TC (efeito borda), pelo aumento da concentração da substância no local;

e) reação pustulosa: é desencadeada por metais, observado principalmente em pacientes atópicos;

f) necrose, escara e quelóide: são reações raras se as substâncias em teste estiverem nas concentrações padronizadas;

g) síndrome da pele excitada (SPE): descrita por Mitchell em 1975, caracteriza-se pela presença de TC positivo, que não são reproduzíveis quando da repetição do TC com as mesmas substâncias, aplicadas isoladamente ou aumentando a distância entre a aplicação das mesmas. A presença de eczema crônico de longo tempo de evolução, de substâncias com afinidades químicas, testadas próximas umas das outras, e de TC com substâncias positivas muito próximas induzem ao estado de hiper-reatividade da pele, levando à presença de TC falso-positivo. A etiopatogenia da SPE está relacionada com uma reação inflamatória do tipo 
irritativa. A melhor maneira de avaliar essa síndrome é a repetição do TC suspeito com distância acima de $05 \mathrm{~cm}$ entre as substâncias, considerando sempre a relevância clínica. ${ }^{13}$

\section{Gravidade/Intensidade do evento adverso relacionado ao estudo}

a) leve ou grau 1: desconforto que não leva à interrupção das atividades diárias;

b) moderado ou grau 2: desconforto suficiente para reduzir ou afetar as atividades diárias;

c) grave ou grau 3: incapacidade de trabalhar ou realizar as atividades diárias. ${ }^{13}$ 


\section{Anexo B - Bateria de testes de contato}

Tabela 5 - Bateria de testes de contato. Grupo brasileiro de estudos em dermatite de contato (GBEDC)

\begin{tabular}{|c|c|c|c|}
\hline $\mathbf{N}^{\mathbf{o}}$ & Substância & Concentração & Veículo \\
\hline 1 & Antraquinona & $2 \%$ & Vaselina Sólida \\
\hline 2 & Bálsamo do Peru & $25 \%$ & Vaselina Sólida \\
\hline \multirow[t]{2}{*}{3} & PPD (MIX) & & \\
\hline & $\begin{array}{l}\text { N-Isopropil, N-Fenil, parafenilenodiamina } \\
\text { N-N Difenil, parafenilenodiamina }\end{array}$ & $0,4 \%$ & Vaselina Sólida \\
\hline 4 & Hidroquinona & $1 \%$ & Vaselina Sólida \\
\hline 5 & Bicromato de Potássio & $0,5 \%$ & Vaselina Sólida \\
\hline 6 & Propilenoglicol & $10 \%$ & Vaselina Sólida \\
\hline 7 & Butil-fenol para-terciário & $1 \%$ & Vaselina Sólida \\
\hline 8 & Neomicina & $20 \%$ & Vaselina Sólida \\
\hline 9 & Irgasan & $1 \%$ & Vaselina Sólida \\
\hline 10 & Kathon CG & $0,5 \%$ & Vaselina Sólida \\
\hline 11 & Cloreto de Cobalto & $1 \%$ & Vaselina Sólida \\
\hline 12 & Lanolina & $30 \%$ & Vaselina Sólida \\
\hline \multirow[t]{3}{*}{13} & Tiuram (MIX) & & \\
\hline & Tetrametiltiuramdissulfito (TMTD) & $1 \%$ & Vaselina Sólida \\
\hline & Tetrametiltiuranmonossulfito (TMTM) & & \\
\hline 14 & Etilenodiamina & $1 \%$ & Vaselina Sólida \\
\hline \multirow[t]{3}{*}{15} & Perfume (MIX) & & \\
\hline & $\begin{array}{l}\text { Álcool cinâmico; Aldeído alfa-amil cinâmico; } \\
\text { Eugenol; Isoeugenol; }\end{array}$ & $7 \%$ & Vaselina Sólida \\
\hline & Geraniol;Hidroxicitronelal; Oak Moss absolute & & \\
\hline \multirow[t]{2}{*}{16} & Mercapto (MIX) & & \\
\hline & $\begin{array}{l}\text { Mercaptobenzotiazol; Dibenzotiazol dissulfeto; } \\
\text { Morfolinilmercaptobenzotiazol; } \\
\text { N-Ciclo-hexil } 2 \text { benzotiazol sulfonamida }\end{array}$ & $2 \%$ & Vaselina Sólida \\
\hline 17 & Benzocaína & $5 \%$ & Vaselina Sólida \\
\hline 18 & Quaternium 15 & $0,5 \%$ & Vaselina Sólida \\
\hline 19 & $\begin{array}{l}\text { Quinolina (MIX) } \\
\text { Clorquinaldol ; Clioquinol }\end{array}$ & $6 \%$ & Vaselina Sólida \\
\hline 20 & Nitrofurazona & $1 \%$ & Vaselina Sólida \\
\hline \multirow[t]{2}{*}{21} & Paraben (MIX) & & \\
\hline & $\begin{array}{l}\text { Metilparaben; Etilparaben; Propilparaben; } \\
\text { Butilparaben; Benzilparaben }\end{array}$ & $15 \%$ & Vaselina Sólida \\
\hline 22 & Resina - Epóxi & $1 \%$ & Vaselina Sólida \\
\hline 23 & Thimerosal & $0,05 \%$ & Vaselina Sólida \\
\hline 24 & Terebintina & $10 \%$ & Vaselina Sólida \\
\hline \multirow[t]{2}{*}{25} & Carba (MIX) & & \\
\hline & $\begin{array}{l}\text { Difenilguanidina; } \\
\text { Dimetilditiocarbamato de zinco; } \\
\text { Dietilditiocarbamato de zinco }\end{array}$ & $3 \%$ & Vaselina Sólida \\
\hline 26 & Prometazina & $1 \%$ & Vaselina Sólida \\
\hline 27 & Sulfato de Níquel & $5 \%$ & Vaselina Sólida \\
\hline 28 & Colofônio & $20 \%$ & Vaselina Sólida \\
\hline 29 & Parafenilenodiamina & $1,0 \%$ & Vaselina Sólida \\
\hline 30 & Formaldeído & $1 \%$ & Água \\
\hline
\end{tabular}

FONTE: Sampaio SAP, Rivitti EA. Erupções eczematosas. In: Sampaio SAP, Rivitti EA, editores. Dermatologia. 3a ed. São Paulo: Artes Médicas; 2007. p.198. 


\section{Anexo C - Procedimentos de coloração para INF- $\gamma$, IL-2, IL-4, IL-10, IL-13, IL-17, IL-23 e TNF- $\alpha$}

\section{IFN- $\gamma$}

a) lavagem: com o tampão EnVision ${ }^{\mathrm{TM}}$ FLEX Wash Buffer diluído 1:20;

b) bloqueio da peroxidase endógena: utilizado em cada zona da lâmina $150 \mu \mathrm{l}$ do reagente EnVision ${ }^{\mathrm{TM}}$ FLEX Peroxidase-Blocking (referência SM801) e incubado por sete minutos. Esta etapa inativa uma enzima existente no tecido/célula, que poderia reagir com outro substrato interferindo na reação;

c) lavagem: com o tampão EnVision ${ }^{\mathrm{TM}}$ FLEX Wash Buffer diluído 1:20;

d) anticorpo primário: realizada diluição 1:500 utilizando diluente redutor de fundo DAKO Antibody Diluent with Background Reducing Components (referência S3022). O tempo de incubação do anticorpo foi de 30 minutos.

e) lavagem: com o tampão EnVision ${ }^{\mathrm{TM}}$ FLEX Wash Buffer diluído 1:20;

f) polímero: utilizado em cada zona da lâmina $150 \mu 1$ do reagente EnVision ${ }^{\mathrm{TM}}$ FLEX/HRP e incubado por 20 minutos. Este reagente consiste em uma estrutura base de dextrano à qual foi associado um vasto número de moléculas de peroxidase (HRP) e moléculas de anticorpos secundários. Utilizou-se uma química exclusiva para a reação de associação, que permite a ligação de, no máximo, 100 moléculas de HRP e de até 20 moléculas de anticorpo por estrutura base;

g) lavagem: com o tampão EnVision ${ }^{\mathrm{TM}}$ FLEX Wash Buffer diluído 1:20;

h) lavagem: com o tampão EnVision ${ }^{\mathrm{TM}}$ FLEX Wash Buffer diluído 1:20;

i) substrato-cromógeno: composto por dois componentes, o EnVision ${ }^{\mathrm{TM}}$ FLEX DAB + Chromogen (referência DM827), uma solução de diaminobenzidina (DAB) concentrada, e EnVision ${ }^{\text {TM }}$ FLEX Substrate Buffer (referência SM803) contendo peróxido de hidrogênio. Antes de utilizá-la, a solução EnVision ${ }^{\mathrm{TM}}$ FLEX DAB + Chromogen foi diluída em tampão EnVision ${ }^{\mathrm{TM}}$ FLEX Substrate Buffer (uma gota de DM827 para cada ml de SM803). O sistema de substrato produz um produto final castanho vivo no local do antígeno alvo. Utilizaram-se $300 \mu 1$ de cromógeno em cada zona da lâmina e incubação por cinco minutos; 
j) lavagem: com o tampão EnVision ${ }^{\mathrm{TM}}$ FLEX Wash Buffer diluído 1:20;

k) contra coloração: utilizados $150 \mu \mathrm{l}$ do reagente EnVision ${ }^{\mathrm{TM}}$ FLEX Hematoxylin (Link) (referência 806) em cada zona da lâmina e incubação por cinco minutos. Este reagente de coloração histológica é adequado para a visualização dos núcleos em cortes de tecido e as preparações de células. Este produto não contém álcool, sendo adequado para utilização com todos os cromógenos utilizados na imunohistoquímica;

1) lavagem: com água destilada;

m)lavagem: com o tampão EnVision ${ }^{\mathrm{TM}}$ FLEX Wash Buffer diluído 1:20;

n) lavagem: com água destilada. ${ }^{79,80}$

\section{IL-2}

a) lavagem: com o tampão EnVision ${ }^{\mathrm{TM}}$ FLEX Wash Buffer diluído 1:20;

b) bloqueio da peroxidase endógena: utilizado em cada zona da lâmina $150 \mu \mathrm{l}$ do reagente EnVision ${ }^{\mathrm{TM}}$ FLEX Peroxidase-Blocking (referência SM801) e incubado por sete minutos. Esta etapa inativa uma enzima existente no tecido/célula, que poderia reagir com outro substrato interferindo na reação;

c) lavagem: com o tampão EnVision ${ }^{\mathrm{TM}}$ FLEX Wash Buffer diluído 1:20;

d) anticorpo primário: realizada diluição 1:500 utilizando diluente redutor de fundo DAKO Antibody Diluent with Background Reducing Components (referência S3022). O tempo de incubação do anticorpo foi de 30 minutos.

e) lavagem: com o tampão EnVision ${ }^{\mathrm{TM}}$ FLEX Wash Buffer diluído 1:20;

f) lavagem: com o tampão EnVision ${ }^{\mathrm{TM}}$ FLEX Wash Buffer diluído 1:20;

g) polímero: utilizado em cada zona da lâmina $150 \mu \mathrm{l}$ do reagente EnVision ${ }^{\mathrm{TM}}$ FLEX/HRP e incubado por 20 minutos. Este reagente consiste em uma estrutura base de dextrano à qual foi associado um vasto número de moléculas de peroxidase (HRP) e moléculas de anticorpos secundários. Utilizou-se uma química exclusiva para a reação de associação, que permite a ligação de, no máximo, 100 moléculas de HRP e de até 20 moléculas de anticorpo por estrutura base;

h) lavagem: com o tampão EnVision ${ }^{\mathrm{TM}}$ FLEX Wash Buffer diluído 1:20;

i) lavagem: com o tampão EnVision ${ }^{\mathrm{TM}}$ FLEX Wash Buffer diluído 1:20; 
j) substrato-cromógeno: composto por dois componentes, o EnVision ${ }^{\mathrm{TM}}$ FLEX DAB + Chromogen (referência DM827), uma solução de diaminobenzidina (DAB) concentrada, e EnVision ${ }^{\text {TM }}$ FLEX Substrate Buffer (referência SM803) contendo peróxido de hidrogênio. Antes de utilizá-la, a solução EnVision ${ }^{\mathrm{TM}}$ FLEX DAB + Chromogen foi diluída em tampão EnVision ${ }^{\mathrm{TM}}$ FLEX Substrate Buffer (uma gota de DM827 para cada ml de SM803). O sistema de substrato produz um produto final castanho vivo no local do antígeno alvo. Utilizaram-se $300 \mu 1$ de cromógeno em cada zona da lâmina e incubação por cinco minutos;

k) lavagem: com água destilada;

1) lavagem: com o tampão EnVision ${ }^{\mathrm{TM}}$ FLEX Wash Buffer diluído 1:20;

m)contra coloração: utilizados $150 \mu 1$ do reagente EnVision ${ }^{\mathrm{TM}}$ FLEX Hematoxylin (Link) (referência 806) em cada zona da lâmina e incubação por cinco minutos. Este reagente de coloração histológica é adequado para a visualização dos núcleos em cortes de tecido e as preparações de células. Este produto não contém álcool, sendo adequado para utilização com todos os cromógenos utilizados na imunohistoquímica;

n) lavagem: com água destilada;

o) lavagem: com o tampão EnVision ${ }^{\mathrm{TM}}$ FLEX Wash Buffer diluído 1:20;

p) lavagem: com água destilada. ${ }^{79,80}$

\section{IL-4}

a) lavagem: com o tampão EnVision ${ }^{\mathrm{TM}}$ FLEX Wash Buffer diluído 1:20;

b) bloqueio da peroxidase endógena: utilizado em cada zona da lâmina $150 \mu 1$ do reagente EnVision ${ }^{\mathrm{TM}}$ FLEX Peroxidase-Blocking (referência SM801) e incubado por sete minutos. Esta etapa inativa uma enzima existente no tecido/célula, que poderia reagir com outro substrato interferindo na reação;

c) lavagem: com o tampão EnVision ${ }^{\mathrm{TM}}$ FLEX Wash Buffer diluído 1:20;

d) anticorpo primário: realizada diluição 1:1000 utilizando diluente redutor de fundo

- DAKO Antibody Diluent with Background Reducing Components (referência S3022). O tempo de incubação do anticorpo foi de 30 minutos.

e) lavagem: com o tampão EnVision ${ }^{\mathrm{TM}}$ FLEX Wash Buffer diluído 1:20;

f) lavagem: com o tampão EnVision ${ }^{\mathrm{TM}}$ FLEX Wash Buffer diluído 1:20; 
g) linker: reagente secundário que amplifica o sinal do anticorpo primário. Foram utilizados $150 \mu \mathrm{l}$ de linker (EnVision ${ }^{\mathrm{TM}}$ FLEX + Mouse (referência 804)) em cada zona da lâmina e incubados por 15 minutos;

h) lavagem: com o tampão EnVision ${ }^{\mathrm{TM}}$ FLEX Wash Buffer diluído 1:20;

i) lavagem: com o tampão EnVision ${ }^{\mathrm{TM}}$ FLEX Wash Buffer diluído 1:20;

j) polímero: utilizado em cada zona da lâmina $150 \mu 1$ do reagente EnVision ${ }^{\mathrm{TM}}$ FLEX/HRP e incubado por 20 minutos. Este reagente consiste em uma estrutura base de dextrano à qual foi associado um vasto número de moléculas de peroxidase (HRP) e moléculas de anticorpos secundários. Utilizou-se uma química exclusiva para a reação de associação, que permite a ligação de, no máximo, 100 moléculas de HRP e de até 20 moléculas de anticorpo por estrutura base;

k) lavagem: com o tampão EnVision ${ }^{\mathrm{TM}}$ FLEX Wash Buffer diluído 1:20;

1) lavagem: com o tampão EnVision ${ }^{\mathrm{TM}}$ FLEX Wash Buffer diluído 1:20;

m)substrato-cromógeno: composto por dois componentes, o EnVision ${ }^{\mathrm{TM}}$ FLEX DAB + Chromogen (referência DM827), uma solução de diaminobenzidina (DAB) concentrada, e EnVision ${ }^{\text {TM }}$ FLEX Substrate Buffer (referência SM803) contendo peróxido de hidrogênio. Antes de utilizá-la, a solução EnVision ${ }^{\mathrm{TM}}$ FLEX DAB + Chromogen foi diluída em tampão EnVision ${ }^{\mathrm{TM}}$ FLEX Substrate Buffer (uma gota de DM827 para cada ml de SM803). O sistema de substrato produz um produto final castanho vivo no local do antígeno alvo. Utilizaram-se $300 \mu 1$ de cromógeno em cada zona da lâmina e incubação por cinco minutos;

n) lavagem: com água destilada;

o) lavagem: com o tampão EnVision ${ }^{\mathrm{TM}}$ FLEX Wash Buffer diluído 1:20;

p) contra coloração: utilizados $150 \mu 1$ do reagente EnVision ${ }^{\mathrm{TM}}$ FLEX Hematoxylin (Link) (referência 806) em cada zona da lâmina e incubação por cinco minutos. Este reagente de coloração histológica é adequado para a visualização dos núcleos em cortes de tecido e as preparações de células. Este produto não contém álcool, sendo adequado para utilização com todos os cromógenos utilizados na imunohistoquímica;

q) lavagem: com água destilada;

r) lavagem: com o tampão EnVision ${ }^{\mathrm{TM}}$ FLEX Wash Buffer diluído 1:20;

s) lavagem: com água destilada. ${ }^{79,80}$ 


\section{IL-10}

a) lavagem: com o tampão EnVision ${ }^{\mathrm{TM}}$ FLEX Wash Buffer diluído 1:20;

b) proteinase K: utilizado $150 \mu \mathrm{l}$ em cada zona da lâmina e incubado por 10 minutos. Responsável pela recuperação antigênica;

c) lavagem: com o tampão EnVision ${ }^{\mathrm{TM}}$ FLEX Wash Buffer diluído 1:20;

d) bloqueio de proteínas: utilizado em cada zona da lâmina $150 \mu$ l (Protein Block Serum - Free (referência X0909)), para reduzir a marcação de fundo, e incubado por 15 minutos;

e) air blow: sopro;

f) anticorpo primário: realizada diluição 1:15000 utilizando diluente redutor de fundo - DAKO Antibody Diluent with Background Reducing Components (referência S3022). O tempo de incubação do anticorpo foi de 10 minutos.

g) lavagem: com o tampão EnVision ${ }^{\mathrm{TM}}$ FLEX Wash Buffer diluído 1:20;

h) lavagem: com o tampão EnVision ${ }^{\mathrm{TM}}$ FLEX Wash Buffer diluído 1:20;

i) polímero: utilizado em cada zona da lâmina $150 \mu \mathrm{l}$ do reagente EnVision ${ }^{\mathrm{TM}}$ FLEX/HRP e incubado por 20 minutos. Este reagente consiste em uma estrutura base de dextrano à qual foi associado um vasto número de moléculas de peroxidase (HRP) e moléculas de anticorpos secundários. Utilizou-se uma química exclusiva para a reação de associação, que permite a ligação de, no máximo, 100 moléculas de HRP e de até 20 moléculas de anticorpo por estrutura base;

j) lavagem: com o tampão EnVision ${ }^{\mathrm{TM}}$ FLEX Wash Buffer diluído 1:20;

k) lavagem: com o tampão EnVision ${ }^{\mathrm{TM}}$ FLEX Wash Buffer diluído 1:20;

1) substrato-cromógeno: composto por dois componentes, o EnVision ${ }^{\mathrm{TM}}$ FLEX DAB + Chromogen (referência DM827), uma solução de diaminobenzidina (DAB) concentrada, e EnVision ${ }^{\mathrm{TM}}$ FLEX Substrate Buffer (referência SM803) contendo peróxido de hidrogênio. Antes de utilizá-la, a solução EnVision ${ }^{\mathrm{TM}}$ FLEX DAB + Chromogen foi diluída em tampão EnVision ${ }^{\mathrm{TM}}$ FLEX Substrate Buffer (uma gota de DM827 para cada ml de SM803). O sistema de substrato produz um produto final castanho vivo no local do antígeno alvo. Utilizaram-se $300 \mu 1$ de cromógeno em cada zona da lâmina e incubação por cinco minutos;

m)lavagem: com água destilada;

n) lavagem: com o tampão EnVision ${ }^{\mathrm{TM}}$ FLEX Wash Buffer diluído 1:20; 
o) contra coloração: utilizados $150 \mu \mathrm{l}$ do reagente EnVision ${ }^{\mathrm{TM}}$ FLEX Hematoxylin (Link) (referência 806) em cada zona da lâmina e incubação por cinco minutos. Este reagente de coloração histológica é adequado para a visualização dos núcleos em cortes de tecido e as preparações de células. Este produto não contém álcool, sendo adequado para utilização com todos os cromógenos utilizados na imunohistoquímica;

p) lavagem: com água destilada;

q) lavagem: com o tampão EnVision ${ }^{\mathrm{TM}}$ FLEX Wash Buffer diluído 1:20;

r) lavagem: com água destilada. ${ }^{79,80}$

\section{IL-13}

a) lavagem: com o tampão EnVision ${ }^{\mathrm{TM}}$ FLEX Wash Buffer diluído 1:20;

b) bloqueio da peroxidase endógena: utilizado em cada zona da lâmina $150 \mu \mathrm{l}$ do reagente EnVision ${ }^{\mathrm{TM}}$ FLEX Peroxidase-Blocking (referência SM801) e incubado por sete minutos. Esta etapa inativa uma enzima existente no tecido/célula, que poderia reagir com outro substrato interferindo na reação;

c) lavagem: com o tampão EnVision ${ }^{\mathrm{TM}}$ FLEX Wash Buffer diluído 1:20;

d) anticorpo primário: realizada diluição 1:800 utilizando diluente redutor de fundo DAKO Antibody Diluent with Background Reducing Components (referência S3022). O tempo de incubação do anticorpo foi de 20 minutos.

e) lavagem: com o tampão EnVision ${ }^{\mathrm{TM}}$ FLEX Wash Buffer diluído 1:20;

f) linker: reagente secundário que amplifica o sinal do anticorpo primário. Foram utilizados $150 \mu \mathrm{l}$ de linker (EnVision ${ }^{\mathrm{TM}}$ FLEX + Mouse (referência 804)) em cada zona da lâmina e incubados por 15 minutos;

g) lavagem: com o tampão EnVision ${ }^{\mathrm{TM}}$ FLEX Wash Buffer diluído 1:20;

h) lavagem: com o tampão EnVision ${ }^{\mathrm{TM}}$ FLEX Wash Buffer diluído 1:20;

i) polímero: utilizado em cada zona da lâmina $150 \mu \mathrm{l}$ do reagente EnVision ${ }^{\mathrm{TM}}$ FLEX/HRP e incubado por 15 minutos. Este reagente consiste em uma estrutura base de dextrano à qual foi associado um vasto número de moléculas de peroxidase (HRP) e moléculas de anticorpos secundários. Utilizou-se uma química exclusiva para a reação de associação, que permite a ligação de, no máximo, 100 moléculas de HRP e de até 20 moléculas de anticorpo por estrutura base; 
j) lavagem: com o tampão EnVision ${ }^{\mathrm{TM}}$ FLEX Wash Buffer diluído 1:20;

k) lavagem: com o tampão EnVision ${ }^{\mathrm{TM}}$ FLEX Wash Buffer diluído 1:20;

1) substrato-cromógeno: composto por dois componentes, o EnVision ${ }^{\mathrm{TM}}$ FLEX DAB + Chromogen (referência DM827), uma solução de diaminobenzidina (DAB) concentrada, e EnVision ${ }^{\mathrm{TM}}$ FLEX Substrate Buffer (referência SM803) contendo peróxido de hidrogênio. Antes de utilizá-la, a solução EnVision ${ }^{\mathrm{TM}}$ FLEX DAB + Chromogen foi diluída em tampão EnVision ${ }^{\mathrm{TM}}$ FLEX Substrate Buffer (uma gota de DM827 para cada ml de SM803). O sistema de substrato produz um produto final castanho vivo no local do antígeno alvo. Utilizaram-se $300 \mu 1$ de cromógeno em cada zona da lâmina e incubação por três minutos;

m)lavagem: água destilada;

n) lavagem: com o tampão EnVision ${ }^{\mathrm{TM}}$ FLEX Wash Buffer diluído 1:20;

o) contra coloração: utilizados $150 \mu \mathrm{l}$ do reagente EnVision ${ }^{\mathrm{TM}}$ FLEX Hematoxylin (Link) (referência 806) em cada zona da lâmina e incubação por cinco minutos. Este reagente de coloração histológica é adequado para a visualização dos núcleos em cortes de tecido e as preparações de células. Este produto não contém álcool, sendo adequado para utilização com todos os cromógenos utilizados na imunohistoquímica;

p) lavagem: com água destilada;

q) lavagem: com o tampão EnVision ${ }^{\mathrm{TM}}$ FLEX Wash Buffer diluído 1:20;

r) lavagem: água destilada. ${ }^{79,80}$

\section{IL-17}

a) lavagem: com o tampão EnVision ${ }^{\mathrm{TM}}$ FLEX Wash Buffer diluído 1:20;

b) bloqueio da peroxidase endógena: utilizado em cada zona da lâmina $150 \mu \mathrm{l}$ do reagente EnVision ${ }^{\mathrm{TM}}$ FLEX Peroxidase-Blocking (referência SM801) e incubado por sete minutos. Esta etapa inativa uma enzima existente no tecido/célula, que poderia reagir com outro substrato interferindo na reação;

c) lavagem: com o tampão EnVision ${ }^{\mathrm{TM}}$ FLEX Wash Buffer diluído 1:20;

d) anticorpo primário: realizada diluição 1:100 utilizando diluente redutor de fundo DAKO Antibody Diluent with Background Reducing Components (referência S3022). O tempo de incubação do anticorpo foi de 30 minutos.

e) lavagem: com o tampão EnVision ${ }^{\mathrm{TM}}$ FLEX Wash Buffer diluído 1:20; 
f) linker: reagente secundário que amplifica o sinal do anticorpo primário. Foram utilizados $150 \mu \mathrm{l}$ de linker (EnVision ${ }^{\mathrm{TM}}$ FLEX + Mouse (referência 804)) em cada zona da lâmina e incubados por 15 minutos;

g) lavagem: com o tampão EnVision ${ }^{\mathrm{TM}}$ FLEX Wash Buffer diluído 1:20;

h) polímero: utilizado em cada zona da lâmina $150 \mu \mathrm{l}$ do reagente EnVision ${ }^{\mathrm{TM}}$ FLEX/HRP e incubado por 20 minutos. Este reagente consiste em uma estrutura base de dextrano à qual foi associado um vasto número de moléculas de peroxidase (HRP) e moléculas de anticorpos secundários. Utilizou-se uma química exclusiva para a reação de associação, que permite a ligação de, no máximo, 100 moléculas de HRP e de até 20 moléculas de anticorpo por estrutura base;

i) lavagem: com o tampão EnVision ${ }^{\mathrm{TM}}$ FLEX Wash Buffer diluído 1:20;

j) lavagem: com o tampão EnVision ${ }^{\mathrm{TM}}$ FLEX Wash Buffer diluído 1:20;

k) substrato-cromógeno: composto por dois componentes, o EnVision ${ }^{\mathrm{TM}}$ FLEX DAB + Chromogen (referência DM827), uma solução de diaminobenzidina (DAB) concentrada, e EnVision ${ }^{\mathrm{TM}}$ FLEX Substrate Buffer (referência SM803) contendo peróxido de hidrogênio. Antes de utilizá-la, a solução EnVision ${ }^{\mathrm{TM}}$ FLEX DAB + Chromogen foi diluída em tampão EnVision ${ }^{\mathrm{TM}}$ FLEX Substrate Buffer (uma gota de DM827 para cada ml de SM803). O sistema de substrato produz um produto final castanho vivo no local do antígeno alvo. Utilizaram-se $300 \mu 1$ de cromógeno em cada zona da lâmina e incubação por cinco minutos;

1) lavagem: água destilada;

m)lavagem: com o tampão EnVision ${ }^{\mathrm{TM}}$ FLEX Wash Buffer diluído 1:20;

n) contra coloração: utilizados $150 \mu \mathrm{l}$ do reagente EnVision ${ }^{\mathrm{TM}}$ FLEX Hematoxylin (Link) (referência 806) em cada zona da lâmina e incubação por cinco minutos. Este reagente de coloração histológica é adequado para a visualização dos núcleos em cortes de tecido e as preparações de células. Este produto não contém álcool, sendo adequado para utilização com todos os cromógenos utilizados na imunohistoquímica;

o) lavagem: com água destilada;

p) lavagem: com o tampão EnVision ${ }^{\mathrm{TM}}$ FLEX Wash Buffer diluído 1:20;

q) lavagem: água destilada. ${ }^{79,80}$ 


\section{IL-23}

a) lavagem: com o tampão EnVision ${ }^{\mathrm{TM}}$ FLEX Wash Buffer diluído 1:20;

b) bloqueio da peroxidase endógena: utilizado em cada zona da lâmina $150 \mu \mathrm{l}$ do reagente EnVision ${ }^{\mathrm{TM}}$ FLEX Peroxidase-Blocking (referência SM801) e incubado por sete minutos. Esta etapa inativa uma enzima existente no tecido/célula, que poderia reagir com outro substrato interferindo na reação;

c) lavagem: com o tampão EnVision ${ }^{\mathrm{TM}}$ FLEX Wash Buffer diluído 1:20;

d) anticorpo primário: realizada diluição 1:100 utilizando diluente redutor de fundo DAKO Antibody Diluent with Background Reducing Components (referência S3022). O tempo de incubação do anticorpo foi de 30 minutos.

e) lavagem: com o tampão EnVision ${ }^{\mathrm{TM}}$ FLEX Wash Buffer diluído 1:20;

f) lavagem: com o tampão EnVision ${ }^{\mathrm{TM}}$ FLEX Wash Buffer diluído 1:20;

g) linker: reagente secundário que amplifica o sinal do anticorpo primário. Foram utilizados $150 \mu 1$ de linker (EnVision ${ }^{\text {TM }}$ FLEX + Mouse (referência 804)) em cada zona da lâmina e incubados por 15 minutos;

h) lavagem: com o tampão EnVision ${ }^{\mathrm{TM}}$ FLEX Wash Buffer diluído 1:20;

i) lavagem: com o tampão EnVision ${ }^{\mathrm{TM}}$ FLEX Wash Buffer diluído 1:20;

j) polímero: utilizado em cada zona da lâmina $150 \mu \mathrm{l}$ do reagente EnVision ${ }^{\mathrm{TM}}$ FLEX/HRP e incubado por 20 minutos. Este reagente consiste em uma estrutura base de dextrano à qual foi associado um vasto número de moléculas de peroxidase (HRP) e moléculas de anticorpos secundários. Utilizou-se uma química exclusiva para a reação de associação, que permite a ligação de, no máximo, 100 moléculas de HRP e de até 20 moléculas de anticorpo por estrutura base;

k) lavagem: com o tampão EnVision ${ }^{\mathrm{TM}}$ FLEX Wash Buffer diluído 1:20;

1) lavagem: com o tampão EnVision ${ }^{\mathrm{TM}}$ FLEX Wash Buffer diluído 1:20;

m)substrato-cromógeno: composto por dois componentes, o EnVision ${ }^{\mathrm{TM}}$ FLEX DAB + Chromogen (referência DM827), uma solução de diaminobenzidina (DAB) concentrada, e EnVision ${ }^{\mathrm{TM}}$ FLEX Substrate Buffer (referência SM803) contendo peróxido de hidrogênio. Antes de utilizá-la, a solução EnVision ${ }^{\mathrm{TM}}$ FLEX DAB + Chromogen foi diluída em tampão EnVision ${ }^{\mathrm{TM}}$ FLEX Substrate Buffer (uma gota de DM827 para cada ml de SM803). O sistema de substrato produz um produto 
final castanho vivo no local do antígeno alvo. Utilizaram-se $300 \mu 1$ de cromógeno em cada zona da lâmina e incubação por cinco minutos;

n) lavagem: água destilada;

o) lavagem: com o tampão EnVision ${ }^{\mathrm{TM}}$ FLEX Wash Buffer diluído 1:20;

p) contra coloração: utilizados $150 \mu \mathrm{l}$ do reagente EnVision ${ }^{\mathrm{TM}}$ FLEX Hematoxylin (Link) (referência 806) em cada zona da lâmina e incubação por cinco minutos. Este reagente de coloração histológica é adequado para a visualização dos núcleos em cortes de tecido e as preparações de células. Este produto não contém álcool, sendo adequado para utilização com todos os cromógenos utilizados na imunohistoquímica;

q) lavagem: com água destilada;

r) lavagem: com o tampão EnVision ${ }^{\mathrm{TM}}$ FLEX Wash Buffer diluído 1:20;

s) lavagem: com água destilada. ${ }^{79,80}$

\section{TNF- $\alpha$}

Após desparafinização dos cortes histológicos em duas incubações com xilol (20 minutos e 10 minutos, respectivamente) e hidratação dos cortes em sequência decrescente de etanol (100\%, 95\% e 70\%), realizou-se o bloqueio de peroxidase endógena com três passagens, de 10 minutos cada uma, em solução de água oxigenada $3 \%$ (10 volumes) em câmara escura. As lâminas foram lavadas em água corrente por cinco minutos, água destilada e PBS pH 7,4.

A exposição antigênica foi realizada com a solução Tris-EDTA pH 9,0 durante 20 minutos, a $95{ }^{\circ} \mathrm{C}$ em banho-maria (DAKO S236784-2), seguido de lavagem em água corrente, água destilada e em tampão PBS por cinco minutos. Fez-se incubação com leite desnatado $10 \%$ em água destilada por 30 minutos à temperatura ambiente.

Realizou-se incubação com o anticorpo primário anti-TNF- $\alpha$ da marca Byorbit diluído em BSA 1\%, "over-night” a $4{ }^{\circ} \mathrm{C}$. Seguiu-se de lavagem em PBS por cinco minutos e em PBS + saponina 0,1\% (um mg de saponina para $100 \mathrm{ml}$ de PBS pH 7.4) por 10 minutos, e incubação com o reagente pós-primário do kit Novo Link (Novocastra) por 30 minutos a $37^{\circ} \mathrm{C}$. Nova lavagem em PBS por cinco minutos, PBS + saponina $0,1 \%$ por 10 minutos e tampão PBS.

Seguiu-se de incubação com o polímero do kit Novo Link (Novocastra) por 30 minutos a $37^{\circ} \mathrm{C}$, lavagem em PBS por 10 minutos e revelação da reação com DAB. 
A solução de DAB (3,3 diaminobenzidina) foi preparada diluindo-se $45 \mathrm{mg}$ deste cromógeno em 100 ml de tampão PBS pH 7.4 e acrescentou-se $1200 \mu$ de água oxigenada $3 \%$.

A intensidade da imunomarcação foi realizada ao microscópio óptico em controles sabidamente positivos que acompanhavam cada reação. Após a revelação da reação, os cortes foram lavados em água corrente e contra corados por um minuto em hematoxilina. Foram novamente lavados em água corrente e desidratados em sequência crescente de etanol e fez-se a montagem das lâminas com resina Permount. 


\section{Anexo D - Técnicas estatísticas}

\section{Métodos}

As técnicas estatísticas utilizadas para a análise dos dados corresponderam aos indicadores da estatística descritiva, como: média, mediana, proporção, desvio padrão e coeficiente de variação. Para estimar a prevalência de células que reagiram positivamente em cada uma das citocinas estudadas, foi utilizada uma medida de tendência central (média aritmética ou mediana) cuja escolha se deu segundo o formato da distribuição de probabilidade que se ajustou melhor aos valores observados em cada citocina. A mediana de uma variável aleatória com função, densidade, distribuição de probabilidade $\mathrm{f}(\mathrm{x})$, foi denotada por M e satisfez relação: $P(X \leq M)=\int_{-\infty}^{M} f(x) d x=0,50$.

Como o gráfico da distribuição de probabilidade teve um formato assimétrico, a mediana foi o melhor indicador para estimar a prevalência. ${ }^{83}$ Posteriormente, foi realizada uma comparação entre a prevalência estimada no eczema agudo e a prevalência estimada no eczema crônico utilizando os testes de hipóteses estatísticos não paramétricos para amostras independentes. A heterogeneidade dos valores de cada citocina foi aproximada através do coeficiente de variação $(\mathrm{CV})$, que é um indicador da variabilidade relativa de um conjunto de dados, definido como: $C V=\frac{\sigma_{x}}{\bar{x}}$, onde $\sigma_{x}$ representou o desvio padrão de uma determinada citocina e $\bar{x}$ a média aritmética dos valores desta citocina.

Os resultados obtidos foram considerados estatisticamente significativos para um nível de erro do tipo I, igual a 0,05 (5\%).

As técnicas estatísticas foram utilizadas para:

a) identificação do formato da distribuição de probabilidade - estimação não paramétrica de uma função de densidade de probabilidade;

b) avaliação da suposição de distribuição normal, através do teste de hipótese desenvolvido por Shapiro e Wilks; 
c) comparação das prevalências observadas, através do teste de hipótese não paramétrico de Mann-Whitney para amostras independentes.

\section{Estimação não paramétrica de funções de densidades}

As técnicas da estatística inferencial (paramétrica) pressupõem que os valores observados em uma determinada variável aleatória sigam um modelo probabilístico conhecido como distribuição de probabilidade normal. ${ }^{83}$ A técnica gráfica utilizada para avaliar tal suposição foi o uso de uma função de densidade de núcleo. Essa função foi a soma ponderada dos valores observados da variável em uma função K, definida como: $\hat{f}_{K}=\frac{1}{q h} \sum_{i=1}^{n} w_{i} K\left(\frac{x-X_{i}}{h}\right)$, sendo $n$ (número de observações), $h$ (número de valores) que foram incluídos na estimação da densidade em cada ponto e $q=\sum_{i=1} w_{i}$. Para a escolha da função $K(\cdot)$, a Epanechnikov foi a mais eficiente na minimização da soma de quadrados médios desse modelo: $K[z]=\left\{\begin{array}{l}\frac{3}{4}\left(1-\frac{1}{5} z^{2}\right) / \sqrt{5} \quad \text { se }|z|<\sqrt{5} \\ 0\end{array}\right.$.

\section{Testes de Shapiro-Wilks}

O teste de Shapiro-Wilks foi desenvolvido como uma alternativa para avaliar a hipótese nula de que um conjunto de dados segue uma distribuição de probabilidade normal. ${ }^{81}$ A estatística do teste é representada por W, $x_{(i)}$ (i-ésima observação ordenada de forma crescente), $\bar{x}$ (média amostral), $a_{i}$ (constante), vetor $m$ (valores esperados das estatísticas de ordem) e a matriz $V$ (matriz de covariâncias entre tais estatísticas de ordem):

$$
W=\frac{\left(\sum_{i=1}^{n} a_{i} x_{(i)}\right)^{2}}{\sum_{i=1}^{n}\left(x_{i}-\bar{x}\right)^{2}} \quad \overrightarrow{a_{1 x n}}=\frac{\overrightarrow{m^{t}} V^{-1}}{\left(\overrightarrow{m^{t}} V^{-1} V^{-1} m\right)^{\frac{1}{2}}}
$$

Para um nível de significância $\alpha$, previamente definido, rejeitou-se a hipótese de normalidade dos dados quando o $p$-value $<\alpha$. 


\section{Teste de Mann-Whitney}

Quando se pretende comparar se duas amostras aleatórias independentes apresentaram o mesmo parâmetro de localização, média/mediana, utiliza-se um teste de hipótese estatístico baseado na distribuição de probabilidade, T-Student. No entanto, é necessário garantir que a característica de interesse seja distribuída segundo uma distribuição de probabilidade normal. O teste de Mann-Whitney é uma alternativa não paramétrica para testar se duas amostras independentes foram retiradas de populações com medianas iguais. Não sendo necessário assumir uma hipótese sobre distribuições de probabilidades populacionais e suas variâncias. ${ }^{83}$

Sejam $\mathrm{P}_{1}$ e $\mathrm{P}_{2}$ duas populações em que $F(X)$ e $G(Y)$ representam suas respectivas funções de distribuição. A hipótese nula deste teste, para todos os valores de $t$, pode ser expressa por $H_{0}: F(X)=G(Y)$. A hipótese alternativa pode ser escrita em termos de um modelo de mudança de posição como $H_{a}: F(X)=G(Y+\Delta){ }^{82}$

A hipótese nula foi rejeitada para um nível de significância estatística de 0,05 (p-value $<0,05)$. 


\section{REFERÊNCIAS}

1. Larsen JM, Bonefeld CM, Poulsen SS, Geisler C, Skov L. IL-23 and TH17mediated inflammation in human allergic contact dermatitis. J Allergy Clin Immunol. 2009;123(2):486-92.

2. Hennino A, Vocanson M, Chavagnac C, Saint-Mezard P, Dubois B, Kaiserlian D, Nicolas JF. Fisiopatologia da dermatite de contato alérgica: papel das células T CD8 efetoras e das células T CD4 regulatórias. An Bras Dermatol. 2005;80(4):335-47.

3. Minang JT, Areström I, Troye-Blomberg M, Lundeberg L, Ahlborg N. Nickel, cobalt, chromium, palladium and gold induce a mixed Th1- and Th2-type cytokine response in vitro in subjects with contact allergy to the respective metals. Clin Exp Immunol. 2006;146(3):417-26.

4. Bordignon V, Palamara F, Cordiali-Fei P, Vento A, Aiello A, Picardo M, Ensoli F, et al. Nickel, palladium and rhodium induced IFN-gamma and IL-10 production as assessed by in vitro ELISpot-analysis in contact dermatitis patients. BMC Immunol. 2008;9:19.

5. Havran WL, Jameson JM. Epidermal $\mathrm{T}$ cells and wound healing. J Immunol. 2010;184(10):5423-8.

6. Martins LEAM, Reis VMS. Imunopatologia da dermatite de contato alérgica. Na Bras Dermatol. 2011;86(3):410-33. 
7. Watanabe H, Gaide O, Pétrilli V, Martinon F, Contassot E, Roques S, et al. Activation of the IL-1 $\beta$-processing inflammasome is involved in contact hypersensitivity. J Invest Dermatol. 2007;127(8):1956-63.

8. Thyssen JP, Linneberg A, Menné T, Johansen JD. The epidemiology of contact allergy in the general population - prevalence and main findings. Contact Dermatitis. 2007;57(5):287-99.

9. Nosbaum A, Vocanson M, Rozieres A, Hennino A, Nicolas JF. Allergic and irritant contact dermatitis. Eur J Dermatol. 2009;19(4):325-32.

10. Kimber I, Basketter DA, Gerberick GF, Dearman RJ. Review allergic contact dermatitis. Int Immunopharmacol. 2002;2(2-3):201-11.

11. Bryld LE, Hindsberger C, Kyvik KO, Agner T, Menné T. Genetic factors in nickel allergy evaluated in a population-based female twin sample. J Invest Dermatol. 2004;123(6):1025-9.

12. Carlsen BC, Andersen KE, Menné T, Johansen JD. Patients with multiple contact allergies: a review. Contact Dermatitis. 2008;589(1):1-8.

13. Sampaio SAP, Rivitti EA. Erupções eczematosas. In: Sampaio SAP, Rivitti EA, editores. Dermatologia. 3a ed. São Paulo: Artes Médicas; 2007. p.189-208.

14. Kaplan DH, Igyártó BZ, Gaspari AA. Early immune events in the induction of allergic contact dermatitis. Nat Rev Immunol. 2012;12(2):114-24.

15. Fonacier LS, Dreskin SC, Leung DYM. Allergic skin diseases. J Allergy Clin Immunol. 2010;125(2 Suppl):S138-49.

16. Vocanson M, Hennino A, Rozières A, Poyet G, Nicolas JF. Effector and regulatory mechanism in allergic contact dermatitis. Allergy. 2009;64(12):1699-714. 
17. Cavani A, Nasorri F, Ottaviani C, Sebastiani S, De Pità O, Girolomoni G. Human $\mathrm{CD} 25+$ regulatory $\mathrm{T}$ cells maintain immune tolerance to nickel in healthy, nonallergic individuals. J Immunol. 2003;171(11):5760-8.

18. Moed H, von Blomberg BME, Bruynzeel DP, Scheper RJ, Gibbs S, Rustemeyer T. Regulation of nickel-induced T-cell responsiveness by CD4+CD25+ cells in contact allergic patients and healthy individuals. Contact Dermatitis. 2005;53(2):71-4.

19. Kawamura T, Ogawa Y, Aoki R, Shimada S. Innate and intrinsic antiviral immunity in skin. J Dermatol Sci. 2014;75(3):159-66.

20. Martinon F, Mayor A, Tschopp J. The inflamasomes: guardians of the body. Annu Rev Immunol. 2009;27(4):229-65.

21. Martin SF. New concept in cutaneous allergy. Contact Dermatitis. 2015;72(1):2-10.

22. Lima HC. Papel das células T reguladoras no desenvolvimento de dermatoses. An Bras Dermatol. 2006;81(3):269-81.

23. Boislève F, Kerdine-Römer S, Rougier-Larzat N, Pallardy M. Nickel and DNCB induce CCR7 expression on human dendritic cells through different signalling pathways: role of TNF- $\alpha$ and MAPK. J Invest Dermatol. 2004;123(3):494-502.

24. Kimber I, Travis MA, Martin SF, Dearman RJ. Immunoregulation of skin sensitization and regulatory T cells. Contact Dermatitis. 2012;67(4):179-83.

25. Honda T, Egawa G, Grabbe S, Kabashima K. Update of immune events in the murine contact hypersensitivity models: toward the understanding of allergic contact dermatitis. J Invest Dermatol. 2013;133(8):303-15.

26. Ashrin MN, Arakaki R, Yamada A, Kondo T, Kurosawa M, Kudo Y, et al. A critical role for thymic stromal lymphopoietin in nickel-induced allergy in mice. J Immunol. 2014;192(9):4025-31. 
27. Gober MD, Gaspari AA. Allergic contact dermatitis. Curr Dir Autoimmun. 2008;10:1-26.

28. Blauvelt A, Hwang ST, Udey MC. Allergic and immunologic diseases of the skin. J Allergy Clin Immunol. 2003;111(2suppl):S560-70.

29. Honda T, Matsuoka T, Ueta M, Kabashima K, Miyachi Y, Narumiya S. Prostaglandin E2-EP3 signaling suppresses skin inflammation in murine contact hypersensitivity. J Allergy Clin Immunol. 2009;124(4):809-18.

30. Nasorri F, Sebastiani S, Mariani V, De Pità O, Puddu P, Girolomoni G, et al. Activation of nickel-specific CD4+ T lymphocytes in the absence of professional antigen-presenting cells. J Invest Dermatol. 2002;118(1):172-9.

31. Xu H, Bjarson B, Elmets CA. Sensitization versus elicitation in allergic contact dermatitis: potencial differences at cellular and molecular levels. Am J Contact Dermatitis. 2000;11(4):228-34.

32. Bangert C, Friedl J, Stary G, Stingl G, Kopp T. Immunopathologic features of allergic contact dermatitis in humans: participation of plasmacytoid dendritic cells in the pathogenesis of the disease? J Invest Dermatol. 2003;121(6):1409-18.

33. Jensen CS, Lisby S, Larsen JK, Veien NK, Menné T. Characterization of lymphocyte subpopulations and cytokine profiles in peripheral blood of nickelsensitive individuals with systemic contact dermatitis after oral nickel exposure. Contact Dermatitis. 2004;50(1):31-8.

34. Traidl C, Sebastiani S, Albanesi C, Merk HF, Puddu P, Girolomoni G, et al. Disparate cytotoxic activity of nickel-specific CD8+ and CD4+ T cell subsets against keratinocytes. J Immunol. 2000;165(6):3058-64.

35. Okazaki F, Kanzaki H, Fujii K, Arata J, Akiba H, Tsujii K, Iwatsuki K. Initial recruitment of producing CD8+ effector cells, followed by infiltration of interferon CD4+ cells in 2,4,6 trinitro-1-chlorobenzeno (TNCB) induced murine contact hypersensitivity reactions. J Dermatol. 2002;29(11):699-708. 
36. He D, Wu L, Kim HK, Li H, Elmets CA, Xu H. CD8+ IL-17-producing T cells are important in effector functions for the elicitation of contact hypersensitivity responses. J Immunol. 2006;177(10):6852-8.

37. Trautmann A, Akdis M, Kleeman D, Altznauer F, Simon HU, Grave T, et al. T cellmediate FAZ-induced keratinocyte apoptosis plays a key pathogenetic role in eczematous dermatitis. J Clin Invest. 2000;106(1):25-35.

38. Zhao Y, Balato A, Fishelevich R, Chapoval A, Mann DL, Gaspari AA. Th17/Tc17 infiltration and associated cytokine gene expression in elicitation phase of allergic contact dermatitis. Br J Dermatol. 2009;161(6):1301-6.

39. Taniguchi M, Harada M, Kojo S, Nakayama T, Wakao H. The regulatory role of Va14 NKT cells in innate and acquired immune response. Annu Rev Immunol. 2003;21(4):483-513.

40. Gober MD, Fishelevich R, Zhao Y, Unutmaz D, Gaspari AA. Humana natural killer $\mathrm{T}$ cells infiltrate into the skin at elicitation sites of allergic contact dermatitis. J Invest Dermatol. 2008;128(12):1460-9.

41. Carbone T, Nasorri F, Pennino D, Eyerich K, Foerster S, Cifaldi L, et al. CD56high $\mathrm{CD}^{-} \mathrm{CD}^{-} 2 \mathrm{~L}^{-} \mathrm{NK}$ cells accumulate in allergic contact dermatitis and contribute to the expression of allergic responses. J Immunol. 2010;184(2):1102-10.

42. Belsito DV. The rise and fall of contact dermatitis. Am J Contact Dermatitis. 1997;8(4):193-201.

43. Trautmann A, Altznauer F, Akdis M, Simon HU, Disch R, Bröcker EB, et al. The differential fate of cadherins during T-cell-induced keratinocyte apoptosis leads to spongiosis in eczematous dermatitis. J Invest Dermatol. 2001;117(10):927-34.

44. Sebastiani S, Albanesi C, Nasorri F, Girolomoni G, Cavani A. Nickel-specific CD4+ and $\mathrm{CD} 8+\mathrm{T}$ cells display distinct migratory responses to chemokines produced during allergic contact dermatitis. J Invest Dermatol. 2002;118(6):1052-8. 
45. Pennino D, Eyerich K, Scarponi C, Carbone T, Eyerich S, Nasorri F, et al. IL-17 amplifies human contact hypersensitivity by licensing hapten nonspecific Th1 cells to kill autologous keratinocytes. J Immunol. 2010;184(9):4880-8.

46. Dearman RJ, Kimber I. Role of CD4+ T helper 2-type cells in cutaneous inflammatory response induced by fluorecein isothicyanate. Immunol. 2000;101(3):442-51.

47. Honda T, Miyachi Y, Kabashima K. Regulatory T cells in cutaneous immune responses. J Dermatol Science. 2011;63(2):75-82.

48. Sakaguchi S, Ono M, Setoguchi R, Yagi H, Hori S, Fehervari Z, et al. Foxp3+CD25+CD4+ natural regulatory $\mathrm{T}$ cells in dominant self-tolerance and autoimmune disease. Immunol Rev. 2006;212(1):8-27.

49. Egawa G, Kabashima K. Skin as a peripheral lymphoid organ: revisiting the concept of skin-associated lymphoid tissues. $J$ Invest Dermatol. 2011;131(11):2178-85.

50. Thyssen JP, Roeske-Nielsen A, Johansen JD. Contact allergy and human biomonitoring - an overview with a focus on metals. Contact Dermatitis. 2011;65(3):125-37.

51. Ross-Hansen K, Johansen JD, Volund A, Menne T, Thyssen JP. The nickel doseresponse relationship by filaggrin genotype (FLG). Contact Dermatitis. 2014;71(1):49-53.

52. Jakobson E, Masjedi K, Ahlborg N, Lundeberg L, Karlberg A-T, Scheynius A. Cytokine production in nickel-sensitized individuals analysed with enzyme-linked immunospot assay: possible implication for diagnosis. $\mathrm{Br} J$ Dermatol. 2002; 147(3):442-9.

53. Minang JT, Areström I, Zuber B, Jönsson G, Troye-Blomberg M, Ahlborg N. Nickel-induced IL-10 down-regulates Th1- but not Th2-type cytokine responses to the contact allergen nickel. Clin Exp Immunol. 2006;143(3):494-502. 
54. Summer B, Paul C, Mazoochian F, Rau C, Thomsen M, Banke I, et al. Nickel (Ni) allergic patients with complications to $\mathrm{Ni}$ containing joint replacement show preferential IL-17 type reactivity to Ni. Contact Dermatitis. 2010;63(1):15-22.

55. Cavani A, Mei D, Guerra E, Corinti S, Giani M, Pirrotta L, et al. Patients with allergic contact dermatitis to nickel and nonallergic individuals display different nickel-specific T cell responses. Evidence for the presence of effector CD8+ and regulatory CD4+ T cells. J Invest Dermatol. 1998;111(4):621-8.

56. Sato N, Kinbara M, Kuroishi T, Kimura K, Iwakura $\mathrm{Y}$, Ohtsu $\mathrm{H}$, et al. Lipopolysaccharide promotes and augments metal allergies in mice, dependent on innate immunity and histidine decarboxylase. Clin Exp Allergy. 2007;37(5):743-51.

57. Schmidt M, Raghavan B, Müller V, Vogl T, Fejer G, Tchaptchet S, et al. Crucial role for human Toll-like receptor 4 in the development of contact allergy to nickel. Nat Immunol. 2010;11(9):814-9.

58. Hanifin JM. Filaggrin mutations and allergic contact sensitization. J Invest Dermatol. 2008;128(6):1362-4.

59. Minang JT, Troye-Blomberg M, Lundebergy L, Ahlborg N. Nickel elicits concomitant and correlated in vitro production of Th1-, Th2-Type and regulatory cytokines in subjects with contact allergy to nickel. Scandinavian Journal of Immunology. 2005;62(3):289-96.

60. Cavani A, Nasorri F, Prezzi C, Sebstiani S, Albanesi S, Girolomoni G. Human CD4+ T lymphocytes with remarkable regulatory functions on dendritic cells and nickel-specific Th1 immune response. J Invest Dermatol. 2000;114(2):295-302.

61. Lindén C, Skare L, Vahter M. Release of nickel coins and deposition onto skin from coin handling - comparing euro coins and SEK. Contac Dermatitis. 2008;59(1):31-7. 
62. Thyssen JP, Johansen JD. Mobile phones are now covered by the European Union Nickel Directive. Contact Dermatitis. 2009;61(1):56-7.

63. Savin J. The rise and fall of nickel allergy. J Cosmet Dermatol. 2003;2(1):57.

64. Garner LA. Contact dermatitis to metals. Dermatol Ther. 2004;17(4):321-7.

65. Jensen P, Thyssen JP, Johansen JD, Skare L, Menné T, Lidén C. Occupational hand eczema caused by nickel and evaluated by quantitative assessment. Contact Dermatitis. 2010;64(1):32-6.

66. Thyssen JP, Johansen JD, Menné T, Lidén C, Bruze M, White IR. Hypersensitivity reactions from metallic implants: a future challenge that needs to be addressed. Br J Dermatol. 2010;162(2):235-6.

67. Jensen P, Johansen JD, Zachariae C, Menné T, Thyssen JP. Excessive nickel release from mobile phones - a persistent cause of nickel allergy and dermatitis. Contact Dermatitis. 2011;65(6):354-8.

68. Gawkrodger DJ, McLeod CW, Dobson K. Nickel skin levels in different occupations and an estimate of the threshold for reacting to a single open application of nickel in nickel-allergic subjects. Br J Dermatolol. 2012;166(1):82-7.

69. Thyssen JP, Linneberg A, Menné T, Nielsen NH, Johansen JD. The association between hand eczema and nickel allergy has weakened among young women in the general population following the Danish nickel regulation: results from two crosssectional studies. Contact Dermatitis. 2009;61(6):342-8.

70. Thyssen JP, Menné T. Metal allergy - a review on exposures, penetration, genetics, prevalence, and clinical implications. Chem Res Toxicol. 2010;23(2):309-18.

71. Ruff CA, Belsito DV. The impact of various patient factors on contact allergy to nickel, cobalt, and chromate. J Am Acad Dermatol. 2006;55(1):32-9. 
72. Duarte I, Amorim JR, Perázzio EF, Schmitz Jr R. Dermatite de contato por metais: prevalência de sensibilização ao níquel, cobalto e cromo. An Bras Dermatol. 2005;80(2):137-42.

73. Sanchez APG, Maruta CW, Sato MN, Ribeiro RL, Zomingnan CA, Nunes RS, Reis VMS. Estudo da proliferação linfocitária em pacientes sensibilizados ao níquel. Na Bras Dermatol. 2005;80(2):149-58.

74. Thyssen JP, Uter W, McFadden J et al. The EU Nickel Directive revised - future steps towards better protection against nickel allergy. Contact Dermatitis. 2011;64(3):121-5.

75. Jacob SE, Moennich JN, McKean BA, Zirwas MJ, Taylor JS. Nickel allergy in the United States: a public health issue in need of a "nickel directive". J Am Acad Dermatol. 2009;60(6):1067-9.

76. Medeiros LM, Fransway AF, Taylor JS, Wyman M, Janes J, Fowler JF, et al. Complementary and alternative remedies: an additional source of potencial systemic nickel exposure. Contact Dermatitis. 2008;58(2):97-100.

77. Duarte I, Lazzarini R, Buense R. Interference the position of substances in an epicutaneous patch battery with the occurrence of false positive results. Am J Contact Dermatitis. 2002;13(3):125-32.

78. Lachapelle JM, Maibach HI. Patch testing and prick testing: a practical guide/Official publication of the ICDRG. 2nd ed. Berlin: Spring-Verlag. 2009. $195 \mathrm{p}$.

79. Sabattini E, Bisgaard K, Ascani S, Poggi S, Piccioli M, Ceccarelli C, et al. The EnVision $^{\mathrm{TM}}$ system: a new immunohistochemical method for diagnostics and research. Critical comparison with the APAAP, ChemMateTM, CSA, LABC, and SABC techniques. J Clin Pathol. 1998;51(7):506-11.

80. Carvalho AL. Avaliação da glicoproteína CRISP-3 como potencialbiomarcador no prognóstico do câncer de próstata [dissertação]. Jataí: Universidade Federal de Goiás; 2016. p.27-8. 
81. Shapiro SS, Wilk MB. An analysis of variance test for normality (complete samples). Biometrika. 1965;52(3/4):591-611.

82. Conover WJ. Practical nonparametric statistics. 3rd ed. New York: Wiley, 1999. $592 \mathrm{p}$.

83. Martins GA, Domingues O. Estatística geral e aplicada. 4a ed. São Paulo: Atlas, 2010. 680p.

84. Borg L, Christensen JM, Kristiansen J, Nielsen NH, Menné T, Poulsen LK. Nickelinduced cytokine production from mononuclear cells in nickel-sensitive individuals and controls. Arch Dermatol Res. 2000;292(6):285-91.

85. Falsafi-Amin H, Holst M, Lundeberg L. Early expression of interleukin-2 mRNA by peripheral blood mononuclear cells isolated from nickel-allergic subjects and subsequently exposed to nickel in vitro. Immunopharmacol Immunotoxicol. 2008;30(2):227-34

86. Falsafi-Amin H, Lundebergb L, Bakhietc M, Nordlind K. Early DNA synthesis and cytokine expression in the nickel activation of peripheral blood mononuclear cells in nickel-allergic subjects. Int Arch Allergy Immunol. 2000;123(2):170-6.

87. Liu J, Harberts R, Tammaro A, Girardi N, Filler RB, Fishelevich R. IL-9 regulates allergen-specific Th1 responses in allergic contact dermatitis. J Invest Dermatol. 2014;134(7):1903-11.

88. Wahlkvist H, Masjedi K, Gruvberger B, Zuber B, Karlberg A-T, Bruze M, et al. The lipophilic hapten parthenolide induces interferon- $\gamma$ ant interleukin-13 production by peripheral blood-derived CD8+ T cells from contact allergic subjects in vitro. Br J Dermatol. 2008;158(1):70-7.

89. Dyring-Andersen B, Skov L, Lovendorf MB, Bzorek M, Sondergaard K, Lauritsen $\mathrm{JPH}$, et al. CD4+ T cells producing interleukin (IL)-17, IL-22 and interferon- $\gamma$ are major effector T cells in nickel allergy. Contact Dermatitis. 2013;68(6):339-47. 
90. Taira M, Sasaki M, Kimura S, Araki Y. Dose-dependent effects of Ni (II) ions on production of three inflammatory cytokine (TNF- $\alpha$, IL-1 $\beta$ and IL-6), superoxide dismutase (SOD) and free radical NO by murine macrophage-like RAW264 cells with or without LPS-stimulation. J Mater Sci. 2008;19(5):2173-8.

91. Pennica D, Nedwin GE, Hayflick JS, Seeburg PH, Derynck R, Palladino MA, et al. Human tumour necrosis factor: precursor structure, expression and homology to lymphotoxin. Nature. 1984;312(5996):724-9.

92. Mesquita Júnior D, Araújo JAP , Catelan TTT, Souza AWS, Cruvinel WM, Andrade LEC, et al. Sistema imunitário - Parte II: Fundamentos da resposta imunológica mediada por linfócitos T e B. Rev Bras Reumatol. 2010;50(5):552-80.

93. Abbas AK, Lichtman AH, Pillai S. Imunologia celular e molecular. 6a ed. Rio de Janeiro: Elsevier; 2008. 294p.

94. Langrish CL, Chen Y, Blumenschein WM, Mattson J, Basham B, Sedgwick JD, et al. IL-23 pathogenic T-cell population induces autoimmune inflammation. $J$ Exp Med. 2005;201(2):233-40. 